\title{
Corpus and Models for Lemmatisation and POS-tagging of Classical French Theatre
}

\author{
Jean-Baptiste Camps ${ }^{1}$, Simon Gabay ${ }^{2}$, Paul Fièvre ${ }^{3}$, Thibault Clérice ${ }^{1}$, Florian Cafiero ${ }^{4}$ \\ ${ }^{1}$ Centre Jean-Mabillon, École nationale des chartes, Université Paris, Sciences \& Lettres \\ ${ }^{2}$ Université de Neuchâtel \\ ${ }^{3}$ Bibliothèque Nationale de France \\ ${ }^{4}$ GEMASS, CNRS / Université Paris-Sorbonne
}

Corresponding author: Jean-Baptiste Camps, Jean-Baptiste.Camps@chartes.ps l.eu

\begin{abstract}
This paper describes the process of building an annotated corpus and training models for classical French literature, with a focus on theatre, and particularly comedies in verse. It was originally developed as a preliminary step to the stylometric analyses presented in Cafiero and Camps [2019]. The use of a recent lemmatiser based on neural networks and a CRF tagger allows to achieve accuracies beyond the current state-of-the art on the in-domain test, and proves to be robust during out-of-domain tests, i.e. up to 20th c. novels.
\end{abstract}

\section{Keywords}

Lemmatisation; POS tagging; 17th c. French; Classical Theatre.

\section{INTRODUCTION}

If many lemmatisers and POS taggers have been trained, and sometimes conceived, for French (e.g. Tellier et al. [2012], Urieli [2013]...), they usually focus on contemporary French and tools for Ancien Régime French remain scarce. One important exception is the TreeTagger [Schmid, 1995] model developed by Diwersy et al. [2017] for the Presto project [Vigier and Blumenthal, 2013-2017]. They have prepared training data with c. 60,000 tokens annotated manually, using an adapted version of MULTEX [Ide and Veronis, 1994] and GRACE [Adda et al., 1998] for the parts of speech (POS), and the Lefff [Sagot, 2010], Morphalou [Romary et al., 2004] and LGeRM [Souvay and Pierrel, 2009] for the lemmas. Unfortunately, training data are not publicly available (yet? $)^{1}$, they are made of non-normalised texts from the 16th to the 18th $\mathrm{c}$. which prevents any comparison task, and no detailed evaluation of the model is offered by the designers of the model.

Recent developments have renewed the field of normalisation, lemmatisation and tagging of historic language varieties, including variation rich languages. Particularly, deep learning methods have been used to establish a new state of the art for Middle Dutch [Kestemont et al., 2016], Medieval Latin [Kestemont and De Gussem, 2017], Medieval Occitan [Camps and Couffignal, 2017], Early Irish [Dereza, 2019] or Middle High German and a variety of other languages [Schmid, 2019, Manjavacas et al., 2019]. Convolutional or (bidirectional) LSTM networks have

\footnotetext{
${ }^{1}$ The Presto data have been entirely revised after the initial publication of this paper (cf. Gabay et al. [2020b]) and are available online at the following address: https://github.com/e-ditiones/LEM1 7.
} 
been put to use, in architecture involving word or character levels representations, for instance word embeddings, and usually a sequence to sequence approach using an encoder-decoder model [Bollmann, 2019], that allow for taking into account the context of a token at either word or character level.

Such architectures are now competing with character level statistical machine translation models for the state of the art of historical text normalisations [Tang et al., 2018, Bollmann, 2019, Gabay and Barrault, 2020]. The developments of such architectures allowed to obtain results in the 89 to $96 \%$ range for lemmatisation of historical languages (and even up to $97.86 \%$ for standard languages like modern French, see Manjavacas et al. [2019]), though they have been showed to be the most dependent on the quantity and quality of training data, outperforming more traditional (essentially, rule based) approaches only when substantial training data is available [Bollmann, 2019].

POS and morphological taggers, especially in the case of morphologically rich languages, have also benefited from neural architectures, with state of the art for modern languages often being attained by recurrent neural nets [Ling et al., 2015, Heigold et al., 2016, Schmid, 2019], with accuracies in the range of $97-98 \%$ for POS and 92-94\% for morphology [Heigold et al., 2016], and more specifically from 90 to $98 \%$ for POS tagging of historical languages [Schmid, 2019, Manjavacas et al., 2019].

In this paper, we present in detail our corpus, the annotation choices, the training set up and finally the results obtained by two models. On the one hand, an "extended" model for lemmatisation of normalised 17 th $\mathrm{c}$. French theatre, i.e. tested specifically for this data, but with enough additional training material to have it perform relatively well on modern (16th c. to 18th c.) and even contemporary (19th c. to 20th c.) French. On the other hand a POS-tagging model including the morphology (gender, number, tense...), based exclusively on 17th c. century training data.

These models were initially developed to allow the stylometric analyses presented in Cafiero and Camps [2019], especially the analyses based on lemma, lemma in rhyme position, and POS 3-grams. In this context, getting results as accurate as possible was a necessary step to ensure the reliability of stylometric results. This initial motivation is reflected in some of the choices of this paper, notably the constitution of the training corpus (which is a sample from the corpus that was to be used in the analyses) ${ }^{2}$.

\section{THE THÉÂTRE CLASSIQUE CORPUS}

Because of its cultural importance for French literature and thanks to a few innovative pioneers, 17th c. French theatre (also called théâtre classique, "classical theatre") benefits from many digital editions freely available online. Among the various projects offering texts online, the Théâtre classique database [Fièvre, 2007, Schöch, 2018] proposes one of the most comprehensive collections. The texts derive from digitisations of 17th $\mathrm{c}$. prints taken from Gallica [Bibliothèque nationale de France, 1997]. The oldest print is usually used, but it is not necessarily the case (for detailed bibliographic information on 17th c. printed theatre, cf. Riffaud [2014]). The text is normalised manually and the spelling aligned with contemporary French ${ }^{3}$

Among all the plays available, 41 comedies (cf.appendix A) have been selected to create a training corpus. They have been written by six different authors spread over two generation:

\footnotetext{
${ }^{2}$ Stylometric results are not presented in this paper. For them, see Cafiero and Camps [2019].

${ }^{3}$ About this (strange) French tradition, cf. Gabay [2014], Duval [2015].
} 
Antoine Le Métel d'Ouville (1589-1655), Jean de Rotrou (1609-1650), Paul Scarron (1610-1660), Pierre Corneille (1606-1684), Molière (1622-1673) and Thomas Corneille (1625-1709). All the plays have been written between the 1630's and the 1670's, that is to say within c. 40 years.

\section{BUILDING AN ANNOTATED CORPUS}

The annotation scheme has been conceived to cope with diachronically spread data, especially earlier periods such as middle and Renaissance French.

\subsection{Choice of authority lists}

Since annotation principles are rather complex, we have decided to publish guidelines separately [Gabay et al., 2020a], and we will summarise here our most important choices.

Regarding POS tags, on top of the aforementioned MULTEX, many possibilities exist: EAGLES [Leech and Wilson, 1996], Ud-Pos [Petrov et al., 2011] and CATTEX [Prévost et al., 2013]. While EAGLES and UD-POS have been developed as international standards, CATTEX has been designed specifically for French medieval texts.

We have decided to choose CATTEX, because we are interested in a long diachronic perspective, and we want to maintain interoperability with several existing corpora that are already using it, such as the Base de français médiéval ("Medieval French Database", cf. Guillot-Barbance et al. [2017]) or the Geste corpus [Camps, 2019] ${ }^{4}$.

The annotation manual of CATTEX09 (Guillot et al. [2013b]) offers a detailed list of tagging rules that we strictly observed. Three options are offered to the annotator: morphological tagging, morpho-syntactical tagging 5 , or both. If adding both labels is ideal (to study processes such as adjectivisation, substantivisation... ) it remains far to costly in time, and we have therefore opted for a simple morpho-syntactical tagging, that appeared at the time as an interesting middle way.

Regarding lemmatisation, we have already mentioned LGeRM, the Lefff and Morphalou. The main interest of the last one, that we have chosen, is that not only the v3.1 includes the Lefff, but it is also used by the Frantext base - the data of which is partially available online to be used as additional material for our model - and the Trésor de la Langue Française informatisé. The LGeRM lexicon is irrelevant in our case, since it is an artificially archaised version of Morphalou to match 17 th and 18 th $\mathrm{c}$. forms. Concerning proper names, we built a specific reference list, thanks to the characters and places index provided by Fièvre [2007], that we expanded when necessary.

Some of our choices diverge from those made by the authors of Morphalou. We were, for instance, more systematic in choosing the masculine singular form as a lemma for nouns (baronne is lemmatised as baron) but not only (la (det. def.) as le, sa or ses (poss.) as son). Concerning personal pronouns, the singular masculine subject (when relevant) case has been used as lemma: direct regimen forms (le, la, les, as in, il les donne) as well as indirect regimen forms (lui, elle(s)) have been lemmatised to the subject masculine singular $(i l)$ - one single pronoun can indeed be subject (il), reflexive (se), direct object (le or en), indirect object (lui or y) or disjunctive (lui). Still in line with our diachronic approach, we kept the difference between the old partitive des

\footnotetext{
${ }^{4}$ It is to be noted that using Cattex does not prevent, in the future, conversions to other tag-sets. For instance, the SRCMF corpus [Prévost and Stein, 2013], originally tagged with Cattex tags, exists in a converted version using UD-POS [Prevost Sophie, Stein Achim, SRCMF, 2020].

${ }^{5}$ With morpho-syntactical tagging, categories are mainly determined in context: il veut le bien (bien is NOMCOm) vs il est bien grand (bien is ADVgen).
} 
(contracted form of de les) and the new non-definite plural article des, and encoded the contracted form $a u(x)$ as $a+l e$.

It has to be noted that, since lemmas are not numbered in Morphalou, it has not been possible to introduce a number-based disambiguation for homographs (e.g., sonl (poss. "his") vs. son2 (noun "sound")... ). Such a situation is however only partially problematic, since it remains possible to distinguish forms thanks to the POS, or the morphology.

\subsection{Texts preprocessing and sampling}

In order to limit model biases, each play of the corpus was sampled to create training and testing data. The text of Fièvre [2007] editions have been tokenised using TXM [Heiden, 2010] XML import. During the import an XSL filter was used to retain only the character's speeches, with exclusion of all other material (stage directions, act and scene numbering...). Out of these data, a three-tier sample was constituted with the 2,000 first tokens of our 41 plays for training data (hereafter train set), the 100 median tokens for validation data (hereafter dev set), and the last 100 for testing data (hereafter test set). Case was not normalised, in order to keep information relevant to the identification of proper names.

The complete XML and annotation workflow is presented in fig. $1^{6}$.

\subsection{Annotation and correction process}

The annotation has been done in three phases. A first Pie [Manjavacas et al., 2019] lemmatisation model has been trained only on the Frantext Open Access data [ATILF-CNRS and Université de Lorraine, 1998-2018], and has been used to annotate a first sample of c. 40,000 tokens, in combination with an available Pie model for POS tags trained on Old French ${ }^{7}$. After being corrected, the same corpus has been used to train new models and annotate c. 40,000 other tokens that were, once again, corrected to create the final training corpus.

Lemma and POS-tags have all been corrected manually. This work was facilitated by the use of Pyrrha [Clérice et al., 2019], a web-based correction interface able to do batch correcting as well as to handle authority lists, allowing efficient collaborative work (fig. 2). Pyrrha also keeps tracks of all changes made on the corpus (fig. 3), and makes it possible to import, correct, share, and download back corpora and authority lists.

\subsection{Expanding annotation through available resources}

If POS-tags have all been systematically corrected, through both linear reading and batch corrections, it is not the case of the morphology, which has only been mostly batch-corrected, because of time concerns. Thus, we can guarantee that every POS tag has been proofread at least once (and usually multiple times), which is not the case for the morphology.

Indeed, to save time, morphological information was not added manually, but was instead projected using the lexicon of inflected forms Morphalou [ATILF-CNRS and Université de

\footnotetext{
${ }^{6}$ Since the initial publication of this article, the effects of Unicode NFKD normalisation have also been tested, with an unclear effect on training accuracy Gabay et al. [2020b].

${ }^{7} \mathrm{~A}$ recent version of the model for Old French can be found as part of the web application Deucalion [Clérice et al., 2019]; they are also directly usable through Pyrrha's interface [Clérice et al., 2019]. Finally, the most up-to-date version of both the Old French and Classical French models is provided, along with functionalities to ease tagging of new documents, as part of the simple pie-extended Python Package [Clérice, 2020]. The models can be procured using their linguistic code ( $\mathrm{f} r \mathrm{O}$ for Old French, $\mathrm{f} \mathrm{r}$ for Classical French) by running the commands: pie-extended download fr and texts can be annotated by pie-extended tag fr MyFile.txt. They also are available online, on the École des chartes' Deucalion instance, at https: / / dh. chartes.psl. eu/deucalion/.
} 
Lorraine, 2016]. To do so, CATTEX POS-tags were mapped to Morphalou's categories (table $1)^{8}$. Then, a simple algorithm looked for matching forms inside Morphalou: when the form was unambiguous, the morphological information was directly retrieved, otherwise the handcorrected POS was used to assess the correct morphological information to retrieve. If none was found, an unknown morph tag was added.

\begin{tabular}{rr||cc||ll} 
CATTEX & Morphalou & CATTEX & Morphalou & CATTEX & Morphalou \\
\hline \hline INJ & Interjection & DETdef & Déterminant & PROord & Nom commun \\
ADVgen & Adverbe & DETndf & Déterminant & PROrel & Pronom \\
ADVneg & Adverbe & DETdem & Déterminant & PROint & Pronom \\
ADVint & Adverbe & DETpos & Déterminant & PROcom & Déterminant \\
ADVsub & Adverbe & DETind & Déterminant & ADJqua & Adjectif qualificatif \\
CONcoo & Conjonction & DETrel & Déterminant & ADJind & Adjectif qualificatif \\
CONsub & Conjonction & DETint & Déterminant & ADJord & Adjectif qualificatif \\
VERcjg & Verbe & DETcom & Déterminant & ADJpos & Adjectif qualificatif \\
VERinf & Verbe & PROper & Pronom & NOMcom & Nom commun \\
VERppe & Verbe & PROimp & Pronom & ADJcar & Nombre \\
VERppa & Verbe & PROadv & Pronom & DETcar & Nombre \\
PRE & Préposition & PROpos & Pronom & PROcar & Nombre \\
& & PROdem & Pronom & &
\end{tabular}

Table 1: Mapping of CATTEX POS-tags to Morphalou categories

Finally, Morphalou's information was converted back to CATTEX09 format, using the mapping presented in table 2.

\begin{tabular}{|c|c|c|c|c|c|}
\hline Morphalou & Cattex & Morphalou & Cattex & Morphalou & Cattex \\
\hline \multicolumn{2}{|c|}{ Mode } & \multicolumn{2}{|c|}{ Temps } & \multicolumn{2}{|c|}{ Nomb. } \\
\hline \multirow{9}{*}{$\begin{array}{l}\text { indicative } \\
\text { imperative } \\
\text { conditional } \\
\text { subjunctive } \\
\text { infinitive } \\
\text { past } \\
\text { participle }\end{array}$} & \multirow{4}{*}{$\begin{array}{l}\text { ind } \\
\text { imp } \\
\text { con } \\
\text { sub }\end{array}$} & \multirow{4}{*}{$\begin{array}{l}\text { present } \\
\text { imperfect } \\
\text { future } \\
\text { simplePast }\end{array}$} & \multirow{4}{*}{$\begin{array}{l}\text { pst } \\
\text { ipf } \\
\text { fut } \\
\text { psp }\end{array}$} & \multirow{2}{*}{$\begin{array}{l}\text { singular } \\
\text { plural }\end{array}$} & \multirow{2}{*}{$\begin{array}{l}\mathrm{s} \\
\mathrm{p}\end{array}$} \\
\hline & & & & & \\
\hline & & & & \multicolumn{2}{|c|}{ Genre } \\
\hline & & & & \multirow{3}{*}{$\begin{array}{l}\text { masculine } \\
\text { feminine } \\
\text { neuter }\end{array}$} & \multirow{3}{*}{$\begin{array}{c}\mathrm{m} \\
\mathrm{f} \\
\mathrm{n}\end{array}$} \\
\hline & - & \multicolumn{2}{|l|}{ Pers. } & & \\
\hline & - & \multirow{4}{*}{$\begin{array}{c}\text { firstPerson } \\
\text { secondPerson } \\
\text { thirdPerson }\end{array}$} & 1 & & \\
\hline & - & & 2 & \multicolumn{2}{|c|}{ Varia } \\
\hline & & & 3 & - & - \\
\hline & & & & $\begin{array}{c}\text { invariable } \\
1036442\end{array}$ & $\begin{array}{c}x \\
\text { ERROR }\end{array}$ \\
\hline
\end{tabular}

Table 2: Mapping of Morphalou to CATTEX flexion tags.

\subsection{Increasing corpus generality with Frantext data}

The Frantext base offers an open access version [ATILF-CNRS and Université de Lorraine, 1998-2018], 32 texts of which have been used to increase the training data (see appendix B). Marginal interventions have been made to correct some systematic errors, but also to ensure its consistency with our annotation choices. For instance, for pronouns (labelled as CLO, CLS and PRO in Frantext data), the lemmas je, me, $m^{\prime}, M^{\prime}$, moi, Moi, were mapped to je; likewise, ils, elle, elles, le, la, les, lui, leur, eux, Ils, Lui, Elle, Elles, to il, etc. On the other hand, some forms of celui and cela were originally lemmatised to $i l$, and we changed the lemmatisation to celui

\footnotetext{
${ }^{8}$ Punctuation and proper names were dealt with separately and specifically, as well as CATTEX combined label, PRE.DETdef. The correspondence between some categories reflect substantial difference in the grammatical typology used. For instance, CATTEX PROord (e.g., 'premier' in 'le premier') match Morphalou's more generic common noun category.For more information on CATTEX categories, see Guillot et al. [2013a].
} 
and cela. Similarly, forms of chacun (or aucun) were lemmatised to un, and we changed it to chacun (or aucun).

We were also more systematic in the alignment of feminine and masculine forms to a single (masculine, singular) lemma, may it be for possessives (mienne, tienne, sienne to mien, tien, sien) or just nouns (hôtesse, amie, veuve, captive, to hôte, ami, veuf, captif, etc).

A few minor corrections of obvious errors were also made (e.g., saurer to savoir), especially regarding homograph forms of some lemmas (e.g., between verbal forms of défaire, "undo', and the noun défaite, "defeat", or between ver, "worm" and vers, "verse"). An additional adjustment has also been made regarding the ligature $\propto$ (cœur), which has been preferred over its decomposed form (coeur).

\section{TRAINING SETUP}

As previously mentioned, many tools are already available. TreeTagger [Schmid, 1995] remains one of the most widely used, even though it is outperformed by other solutions. For the French language, TALISMAN [Urieli, 2013] or MElt Sagot [2016] are commonly used by the NLP community, but many other solutions are available such as Lemming (only for lemmas, cf. Müller et al. [2015]), Marmot (only for POS, cf. Müller et al. [2013]) or Pie (mainly for lemmas, cf. Manjavacas et al. [2019]). We have decided to use the two latter.

\subsection{Lemmatisation}

Concerning Pie as a lemmatiser, we tested three different configurations (table 3):

1. base (sent-Im), default configuration, based on the configuration that achieved best accuracy described in Manjavacas et al. [2019], using sentence context, RNN character embeddings, as well as forward and backward language models ${ }^{9}$;

2. wembs the same as the previous one, but with the adjunction of word embeddings, initialised using pretrained embeddings;

3. bert same as the previous one, but using CamemBERT embeddings [Martin et al., 2019], reduced from 768 to 150 dims;

4. cnn+wembs a configuration using $\mathrm{CNN}$ character embeddings, with word embeddings, based on skipgram on a larger unlemmatised corpus. This configuration is the one used for Cafiero and Camps [2019], with limited additional tuning.

\begin{tabular}{c|cccc} 
& context & char embs & word embs & hidden size \\
\hline \hline base & sentence & rnn 300 dims & 0 & 150 \\
wembs & sent.+word & rnn 300 dims & $150 \mathrm{dims}$ & 150 \\
bert & sent.+word & rnn 300 dims & 768 to $150 \mathrm{dims}$ & 150 \\
cnn+wembs & sent.+word & cnn 150 dims & $150 \mathrm{dims}$ & 150
\end{tabular}

Table 3: Configurations tested with Pie

For each configuration, due to the stochastic nature of the process, five models were trained, using early stopping with threshold 0.001 and patience 6 , and the best one was retained.

For the third configuration, word-embeddings were pretrained using Word2Vec Python implementation, on a large corpus of 343 theatre texts from Fièvre [2007] and those of the Frantext Open Access that we presented supra, for a total of c. $7 \mathrm{M}$ tokens.

\footnotetext{
${ }^{9}$ For this configuration, we used a config file provided to us by Enrique Manjavacas, main developer of Pie.
} 


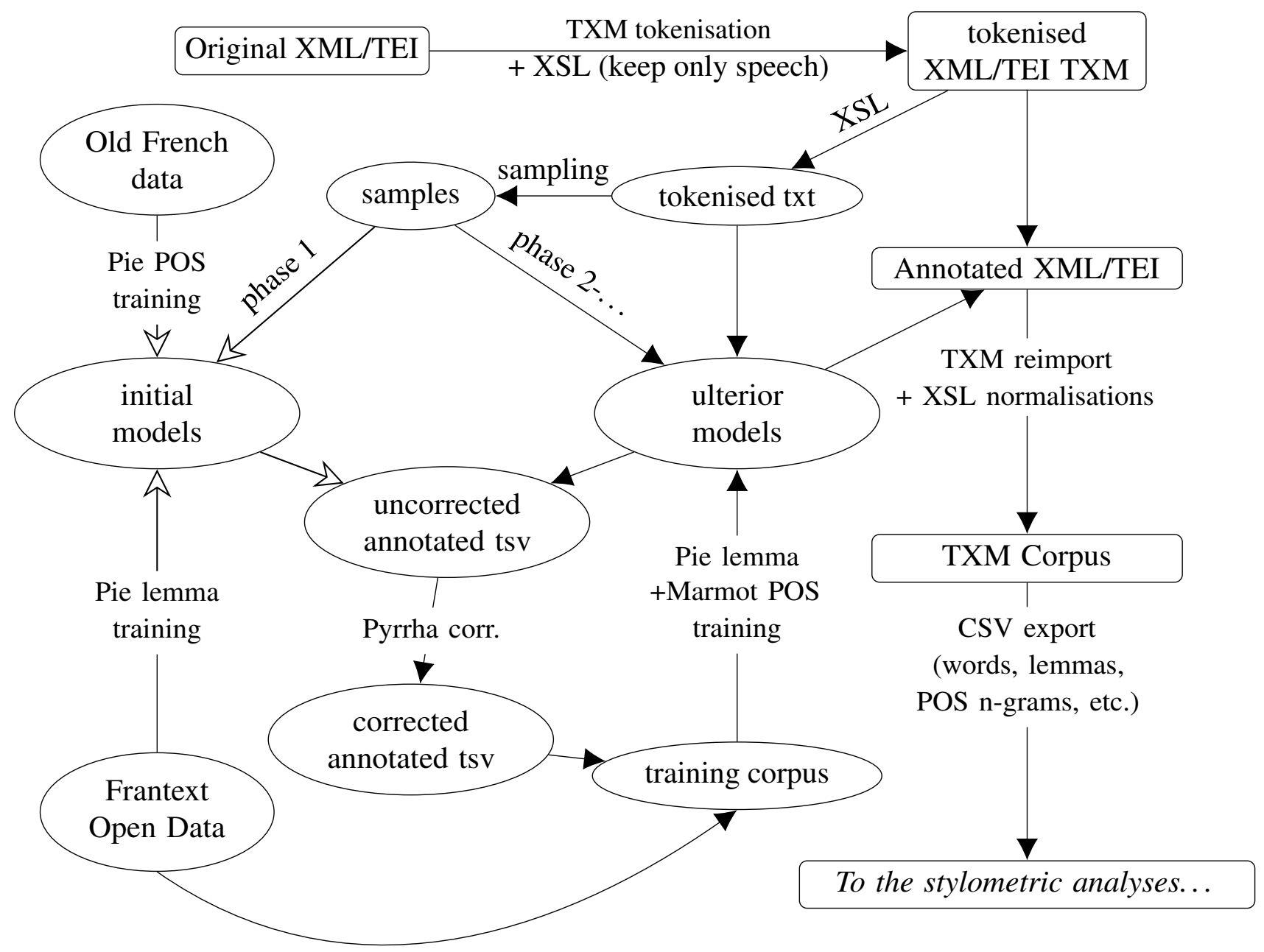

Figure 1: Workflow for building the training corpus and models (ellipses) and the annotated XML corpus used for stylometric analysis (rectangles); void-arrowheads specify steps particular to the initial model building phase 


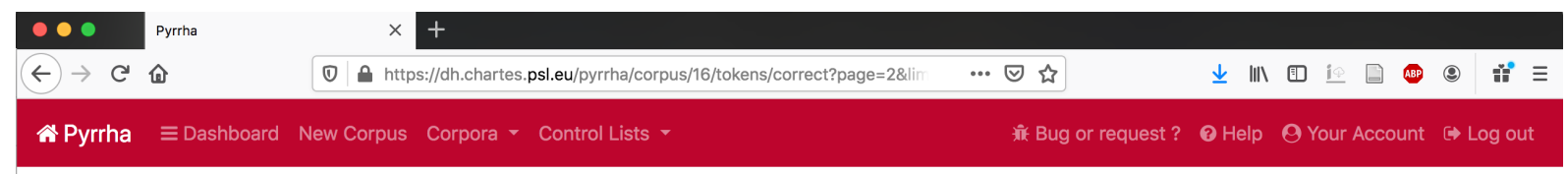

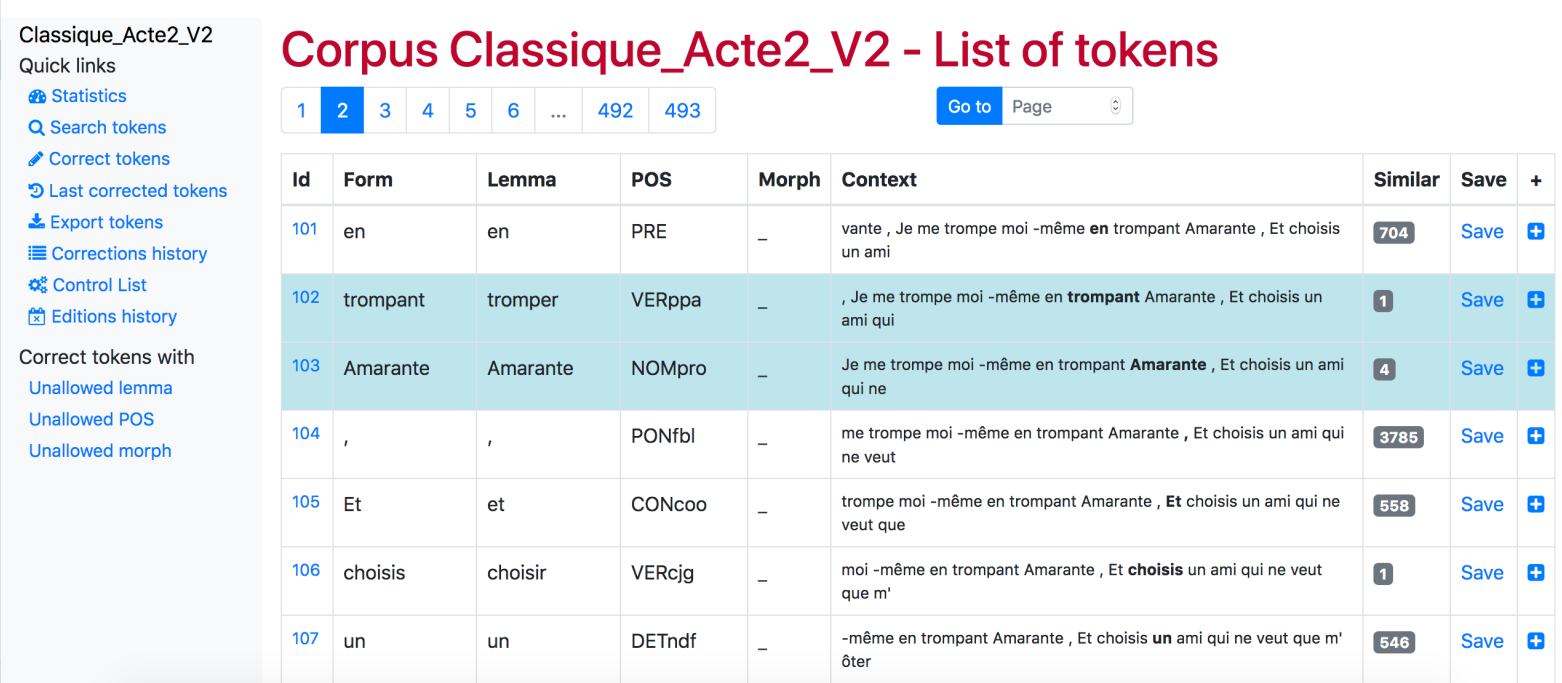

Figure 2: Screenshot of the Pyrrha interface: main correction view 


\section{Corpus Classique_Acte2_V2 - List of tokens}

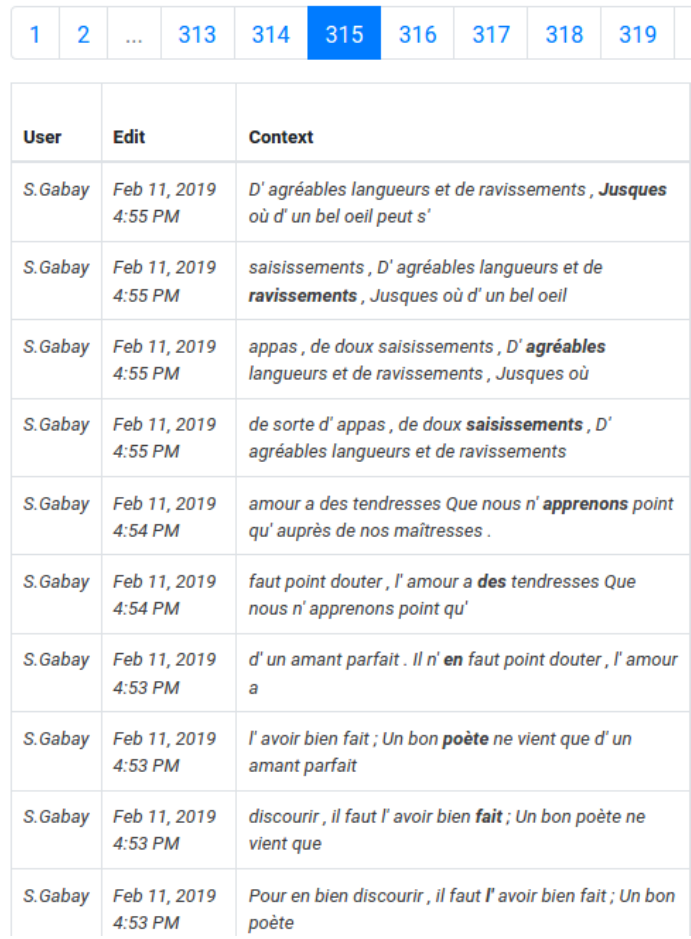

\begin{tabular}{|c|c|}
\hline 336 & Go to Page \\
\hline d Lemma & Corr Lemma \\
\hline sque & jusque \\
\hline vissement & ravissement \\
\hline réable & agréable \\
\hline isissement & saisissement \\
\hline prendre & apprendre \\
\hline _le & un \\
\hline & en \\
\hline ète & poète \\
\hline re & faire \\
\hline & le \\
\hline
\end{tabular}

\begin{tabular}{|c|c|c|c|c|}
\hline $\begin{array}{l}\text { Previous } \\
\text { POS }\end{array}$ & $\begin{array}{l}\text { Actual } \\
\text { POS }\end{array}$ & $\begin{array}{l}\text { Previous } \\
\text { Morph }\end{array}$ & $\begin{array}{l}\text { Actual } \\
\text { Morph }\end{array}$ & Similar \\
\hline VERcjg & PRE & - & - & 0 similar \\
\hline VERcjg & NOMcom & _- & _- & 0 similar \\
\hline NOMcom & ADJqua & - & - & 0 similar \\
\hline VERcjg & NOMcom & _- & - & 0 similar \\
\hline NOMcom & VERcjg & - & - & 0 similar \\
\hline DETndf & DETndf & - & _- & 82 similar \\
\hline PRE & PROadv & _- & - & 334 similar \\
\hline VERcjg & NOMcom & - & - & 0 similar \\
\hline VERcjg & VERppe & - & _- & 76 similar \\
\hline DETdef & PROper & _- & _- & 435 similar \\
\hline
\end{tabular}

Corpus Classique_Acte2_V2

Statistics

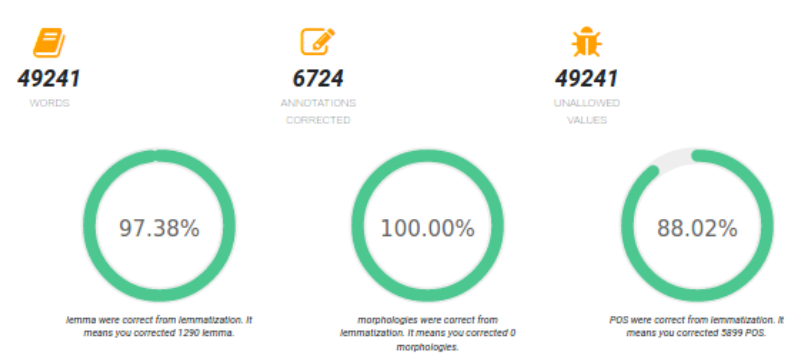

Annotations over time

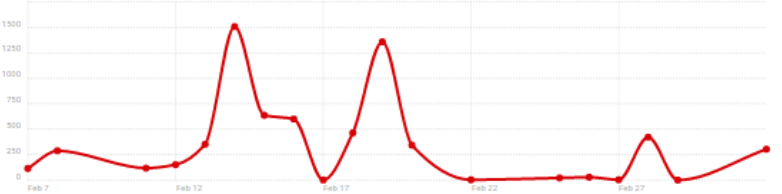

Most common corrections
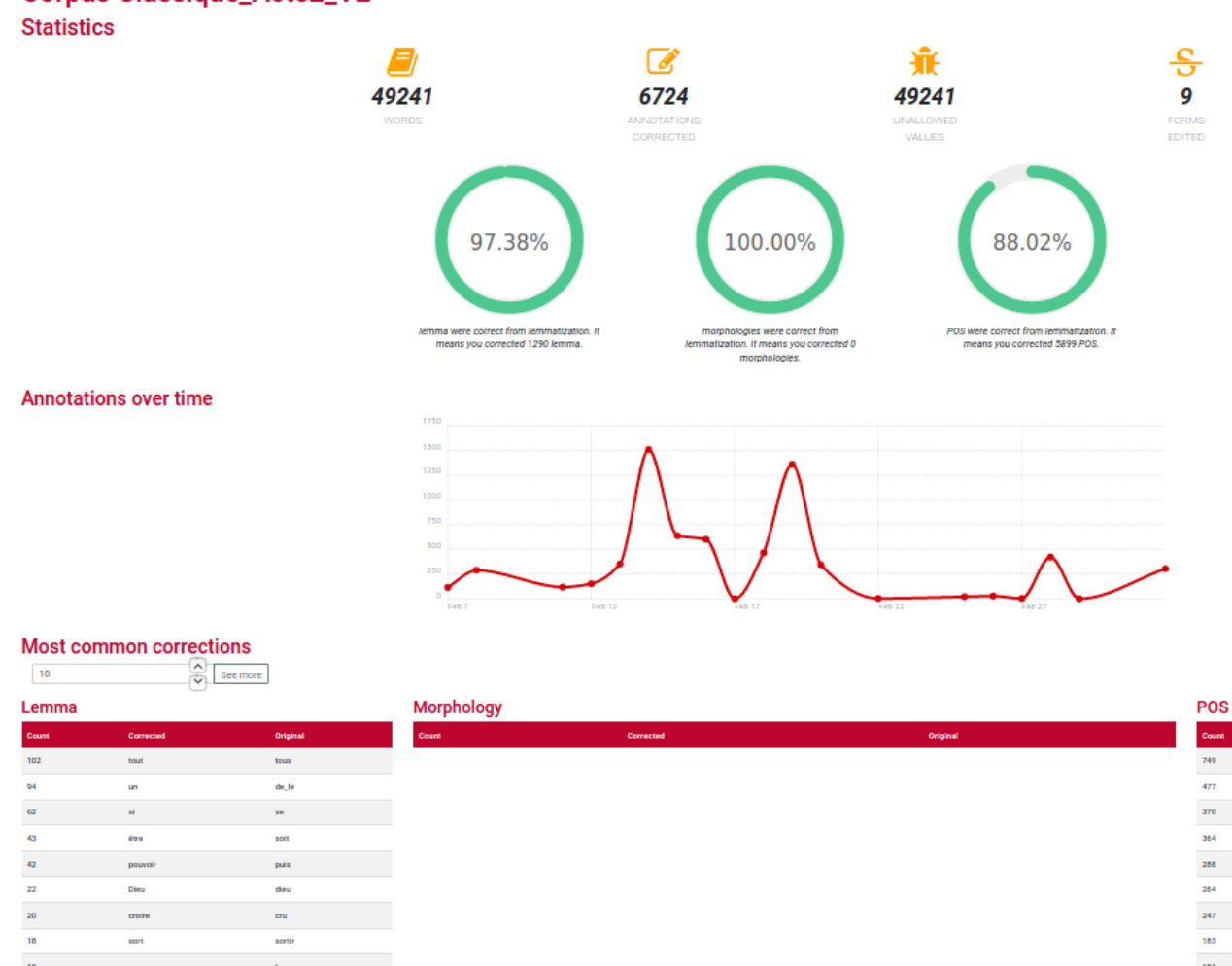

POS

Count Corrected Original

\begin{tabular}{|lll}
\hline 749 & NOMcom & VERcjg \\
\hline 477 & PROper & DETdef \\
\hline 370 & PROadv & PRE \\
\hline 364 & PROrel & CONsub \\
\hline 288 & VERcjg & NOMcom \\
\hline
\end{tabular}

Figure 3: Screenshot of the Pyrrha interface: correction history and corpus statistics 


\subsection{POS tagging}

For POS-tagging, we trained both Marmot and Pie on the training data we produced, without further augmentation. The configurations were the following:

1. Marmot: base configuration provided with Marmot, using the dev set during training, and the test set for final evaluation;

2. Pie: same configurations that for lemmatisation (base (sent-lm), wembs and bert, see above and table 3) but with a CRF output layer to predict part-of-speech tags;

3. +aux: for each of the POS-tagging configuration, we tried to see if we could obtain a gain in accuracy by using auxiliary tasks (the tasks used can be seen in table 2 in bold, with the addition of Case, mainly used for personal pronouns). In a multi-task setting, we trained linear classifiers for each morphological feature, but sharing weights with the main task (POS prediction).

\section{RESULTS}

\subsection{Calibration and in-domain tests}

Results of the Pie lemmatisation training are presented in table 4. The best Pie model (configurations 2, wembs) achieved $99.09 \%$ accuracy on the test set. The results obtained with Marmot and Pie for POS on the test set are presented in table 5, and the best results are achieved by the wembs+aux configuration. Yet, in both cases, the variation between the accuracies are relatively low, and not substantially higher than random variations between different iterations of the same configuration.

\begin{tabular}{c|rrrrr} 
& base & wembs & bert & cnn-wembs & support \\
\hline \hline all & 98.80 & $\mathbf{9 9 . 0 9}$ & 98.95 & 98.80 & 4181 \\
unknown tokens & 70.31 & 71.88 & $\mathbf{7 6 . 5 6}$ & 65.62 & 64 \\
ambiguous tokens & 97.32 & $\mathbf{9 8 . 0 2}$ & 97.43 & 97.43 & 857 \\
unknown targets & 50.00 & 57.14 & $\mathbf{8 5 . 7 1}$ & 57.14 & 14
\end{tabular}

Table 4: Pie lemmatisation accuracies on the test set for the best model for each configuration. "Unknown tokens" are tokens never seen during training, while "ambiguous tokens" are forms that can correspond to different lemmas. "Unknown targets" are lemmas never seen in training, but that the neural network can still sometimes accurately predict, thanks to its character level modelling.

\begin{tabular}{c||r|rrrrrrr} 
& Marmot & \multicolumn{8}{|c}{ Pie } \\
\hline & base & base & +aux & wembs & +aux & bert & +aux & support \\
\hline \hline All & 96.87 & 96.72 & 96.51 & 96.84 & $\mathbf{9 7 . 0 1}$ & 96.65 & 96.15 & 4181 \\
Ambiguous tokens & NA & 91.86 & 91.43 & $\mathbf{9 2 . 4 0}$ & 92.29 & 91.76 & 90.36 & 934 \\
Unknown tokens & 82.57 & $\mathbf{8 6 . 2 4}$ & $\mathbf{8 6 . 2 4}$ & 78.44 & 81.65 & 76.61 & 73.39 & 218
\end{tabular}

Table 5: Results obtained for POS by the Marmot and Pie models on the test set. For the Pie models, we confronted trainings with or without morphology as auxiliary tasks.

\subsection{Out-of-domain tests}

To evaluate the ability of the best models to generalise for data from other periods, we conceived two out-of-domain corpora. Since we want to evaluate generality with regard to diachronic, diaphasic and diagenic (i.e. gender based) variation, we have selected samples from 16th to the 20th century texts, either from theatre plays or from a variety of genres outside theatre, literary or practical (administrative texts, correspondence, etc.), from male and female authors, in order to have: 
- 20 samples of roughly 100 tokens for each century, 10 of theatre plays, 10 of a variety of other genres;

- roughly as much tokens written by men or women for each century;

- a comparable distribution of tokens by genres for each century.

In addition, for the samples concerning 17th century theatre, we excluded verse comedies in general, and the authors from which were drawn our training corpus. A complete list is given in appendix $\mathrm{C}$.

We evaluate the best models (wembs and wembs+aux) for lemma and for POS on the out-ofdomain data (table 6 and 7).

\begin{tabular}{c|rrrrr|r}
\multicolumn{8}{c}{ LEMMA } \\
\hline \hline Corpus & 16th & 17th & 18th & 19th & 20th & All cent. \\
\hline Theatre & 97.60 & 98.10 & 98.88 & 98.34 & 98.00 & 98.19 \\
Not theatre & 97.78 & 98.02 & 98.06 & 96.97 & 97.39 & 97.65 \\
Both & 97.69 & 98.06 & 98.46 & 97.66 & 97.70 & 97.92
\end{tabular}

Table 6: Lemmatisation accuracies of the best models on out-of-domain data

\begin{tabular}{c|rrrrr|r}
\multicolumn{8}{c}{ POS } \\
\hline \hline Corpus & 16th & 17th & 18th & 19th & 20th & All cent. \\
\hline Theatre & 95.05 & 96.59 & 95.98 & 94.81 & 93.57 & 95.18 \\
Not theatre & 92.89 & 94.27 & 96.53 & 91.87 & 91.35 & 93.42 \\
Both & 93.93 & 95.44 & 96.27 & 93.36 & 92.48 & 94.30
\end{tabular}

Table 7: POS accuracies of the best models on out-of-domain data

The lemmatisation model proves to be relatively robust: globally, the loss of accuracy is of roughly 1 percentage point, while it is closer to 3 percentage points for the POS model. This difference can be explained by the difference between the training corpora: the use of significant additional data to improve the efficiency of the lemmatisation model seems to reflect in its greater capacity to generalise. The same reason could also explain why the lemmatisation models transpose better to non-dramatic texts than the POS model.

In both cases, though, the better accuracies are reached for the 17th and 18th centuries - and, surprisingly, more specifically for 18th century data in most cases. It progressively decreases going backward or forward in time.

\subsection{Improvement over previous corpus}

In order to evaluate the importance of the addition of the newly annotated data (Theatre), we setup a second training experiment where we reuse the best configuration found in 4.1 (wembs) over 5 iterations using the same training, dev and test set, except for the files from the Theatre sample in train and dev. Using the best model, we are able to measure the effect of the introduction of Theatre data on top of the Frantext data. On lemmatization, the results are clear: the overall accuracy with the same configuration goes from $97.30 \%$ to $99.09 \%$, an increase of 1.79 points. We cannot compare unknown and ambiguous tokens as well as unknown tokens as the support from these categories moved: -88 unknown tokens, +34 ambiguous tokens, -23 unknown targets. The same impact can be seen on out-of-domain data (Table 8 ) with a more visible impact on the Theatre corpus of the 18 th century ( +0.96 points). Strangely enough, neither the 17 th century or the Theatre genre benefits the most from the inclusion of 17th century Theatre data, as the Not Theatre corpus and the 18th century are the most improved ones. 


\begin{tabular}{l|rrrrr|r} 
Corpus & $\mathbf{1 6}$ & $\mathbf{1 7}$ & $\mathbf{1 8}$ & $\mathbf{1 9}$ & $\mathbf{2 0}$ & All cent. \\
\hline \hline Theatre & +0.16 & +0.30 & +0.96 & +0.00 & +0.22 & +0.32 \\
Not theatre & +0.74 & +0.46 & +0.63 & +0.30 & +0.67 & +0.56 \\
Both & +0.46 & +0.38 & +0.79 & +0.07 & +0.44 & +0.45
\end{tabular}

Table 8: Score improvements between Frantext corpus and Frantext+Theatre. Reads as follow: on 17th century theatre, a model trained with Frantext + Theatre has +0.30 points of accuracy, going from 97.80 to $98.10 \%$.

\subsection{Most frequent confusions}

The most frequent confusions of the best models on the out-of-domain data are presented in table 9 .

\begin{tabular}{|c|c|c|c|c|c|c|c|}
\hline Expected & Tot. Err. & Pred. & Pred. times & Expected & Tot. Err. & Pred. & Pred. times \\
\hline \multicolumn{4}{|c|}{ LEMMA } & \multicolumn{4}{|c|}{ POS } \\
\hline monsieur & 9 & M. & 9 & NOMcom & 182 & ADJqua & 45 \\
\hline le & 9 & il & 9 & & & NOMpro & 33 \\
\hline \multirow[t]{2}{*}{ cœur } & 6 & cuur & 4 & & & VERinf & 32 \\
\hline & & crur & 2 & & & VERcjg & 18 \\
\hline franc & 6 & Franc & 6 & & & VERppe & 11 \\
\hline \multirow[t]{2}{*}{ Électre } & 5 & éLECTRE & 4 & ADJqua & 104 & NOMcom & 45 \\
\hline & & électre & 1 & & & VERppe & 17 \\
\hline noble & 4 & Nobles & 4 & & & VERcjg & 12 \\
\hline maître & 4 & maîtresse & 4 & NOMpro & 81 & NOMcom & 43 \\
\hline de_le & 4 & un & 4 & VERcjg & 61 & NOMcom & 18 \\
\hline un & 4 & de_le & 4 & & & ADJqua & 12 \\
\hline \multirow[t]{2}{*}{ dame } & 3 & Dame & 2 & & & VERppe & 12 \\
\hline & & damer & 1 & ADVgen & 58 & NOMcom & 16 \\
\hline \multirow{2}{*}{$\begin{array}{c}\text { Phanor } \\
\text { voir }\end{array}$} & 3 & phanor & 3 & & & VERcjg & 14 \\
\hline & 3 & vivre & 3 & PROrel & 31 & CONsub & 26 \\
\hline Vosges & 3 & vosge & 3 & & & & \\
\hline Médée & 3 & médé & 3 & & & & \\
\hline
\end{tabular}

Table 9: Sample from the confusion matrix for the best Pie models on the out-of-domain data.

Regarding lemmatisation, some errors related to homographs such as the token le (regimen pronoun $(i l)$ or determiner (le); or the token des (plural of the determiner un or partitive de_le). Some other errors are due to abbreviations not present in the training data (M. for monsieur). More interestingly, for the research of potential improvements, many errors are related to rare characters classes in the training data, such as capital letters or ligatures $(\propto)$.

For POS, the most frequent confusions are in nominal rather than verbal tags. In particular, confusions between common nouns (NOMcom), proper nouns (NOMpro), adjectives (AD Jqua) and nominal forms of the verbs (participle, VERppe, and infinitive, VERinf). Some errors are due to the morpho-syntactic nature of our annotation, which, for instance, labels substantive adjective as common nouns (le beau is NOMcom).

\section{DISCUSSION}

The scores of up to $99 \%$ for in-domain lemmatisation and $97 \%$ for POS tagging put our best models above the expected state of the art, or in it's upper range (see I). Yet, these results were deserving of further investigation, through out-of-domain tests and more qualitative inspection. 
Out-of-domain tests show that, even though they were trained for 17th century classical theatre, the model reach their best accuracies for 18th century texts. Such a fact seems counter-intuitive, but a plausible explanation might be as follow: the median date of the texts of the Frantext corpus is 1872 , and mean date is 1859 . By adding roughly $80 \mathrm{k}$ tokens of 17 th century texts to the 2,3M of Frantext (with mean text date 1859), we may have somehow slightly pulled the corpus closer to the 18th century.

In any case, through the careful construction of a labelled corpus and the use of a neural lemmatiser and tagger, we were able to develop models very suitable to the annotation necessary for the stylometric analyses showed in Cafiero and Camps [2019]. But we think that the model are useful for the annotation of 17th century theatre, and even beyond that, of Early Modern French texts in normalised spelling, with encouraging results regarding generalisation beyond the original scope of the experiments.

\section{FURTHER RESEARCH}

Looking at our results, the main lead for improvements should be a more efficient way to deal with rare character classes, such as capital letters, diacritics or ligatures. Several methods could be used to reduce the number of classes (e.g., Unicode decomposed normalisation) or, alternatively, the training set could be sufficiently extended to provide enough cases.

More generally, three possible directions could be followed in the coming years. The first is to expand the training corpus to other dramatic genres (tragedy, tragi-comedy...), and other genres in general (poetry, novels, short stories...). The second would be to replace normalised tokens by non-normalised ones, and therefore offer a new model that takes full advantage of the ability of tools like Pie to deal with spelling variation in historical languages, and, doing so, strengthen the ability of model to deal with older varieties of French. The third is to expand dramatically the training with data taken from 18th or 16th c. texts. Results going in these directions and continuing the experiments described in this paper will be presented at DTUC'20 [Gabay et al., 2020b].

\section{AUTHOR CONTRIBUTIONS}

P.F. encoded the corpus and all its metadata. F.C., J.-B. C. and S.G. designed the research project. The preprocessing of the texts, the initial setup of the Pyrrha corpus and of the authority lists were performed by J.-B. C. Correction of the training data and expansion of the authority lists was shared equally between F.C., J.-B. C. and S.G. Post-processing of the trained corpus, injection of morphological data, and correction of the Frantext data was done by J.-B. C., as well as the training, testing of the models and their further use to annotate unseen data. T.C. programmed modifications to Pie code to include Bert and participated in the training and benchmarking of models, as well as additional debugging of the annotation tools. All authors contributed to the writing of this paper.

The authors have no competing interests to declare.

\section{MATERIALS AND DATA AVAILABILITY}

The most up-to-date version of the models can be easily obtained and used thanks to the pie-extended Python package, available on Pypi (https://pypi.org/project/ pie-extended/), with the command pie-extended download fr, and can be queried at https://tal.chartes.psl.eu/deucalion/. 
The initial version created for Cafiero and Camps [2019] is available from the Science Advances website since the publication of the paper, on 27th Nov. 2019 at this address: https: / / advances.sciencemag.org/highwire/filestream/221312/field_highwire_adjunct_files/0/aax5489_Data_file_S1.zip. The initial version of the models is available on Zenodo (10.5281/zenodo.3353421).

The version of the best models described in this paper, as well as training, validation and test data can be found on Zenodo as well, as version 3 of the same repository (doi: 10.5281/zenodo.3828644).

Licensing is specified separately for each repository.

\section{ACKNOWLEDGEMENTS}

We thank the DIM Science du texte et connaissances nouvelles for funding the acquisition of a GPU server, as well as the École nationale des chartes for providing infrastructure and support for the server. We thank Enrique Manjavacas for his precious advice regarding lemmatisation and Pie configuration, as well as Marie Puren for her help with the annotation of 20th century texts.

\section{References}

Gilles Adda, Joseph Mariani, Josette Lecomte, Patrick Paroubek, and Martin Rajman. The grace french part-ofspeech tagging evaluation task. In Proc. of LREC'98 (1st International Conference on Language Resources and Evaluation), 1998. URL https://infoscience.epfl.ch/record/98004.

ATILF-CNRS and Université de Lorraine. Base textuelle Frantext: Démonstration, 1998-2018. URL https : //www.frantext.fr/repository/frantext-demo/.

ATILF-CNRS and Université de Lorraine. Morphalou v3.1, 2016. URL https://www.ortolang.fr/ market/lexicons/morphalou.

Bibliothèque nationale de France. Gallica - bibliothèque numérique de la bnf, 1997. URL https://gallica. bnf.fr.

Marcel Bollmann. A Large-Scale Comparison of Historical Text Normalization Systems. Proceedings of the 2019 Conference of the North, pages 3885-3898, 2019. doi: 10.18653/v1/N19-1389. URL http: / / arxiv . org/ abs/1904.02036.

Florian Cafiero and Jean-Baptiste Camps. Why Molière most likely did write his plays. Science Advances, 5(11), 2019. doi: 10.1126/sciadv.aax5489. URL https://advances.sciencemag.org/content/5/11/ eaax5489.

Jean-Baptiste Camps, editor. Geste: un corpus de chansons de geste, 2016-... (Version 02). École nationale des chartes, Paris, April 2019. URL http://doi.org/10.5281/zenodo.2630574. textes du domaine public, développements CC-BY-SA.

Jean-Baptiste Camps and Gilles Guilhem Couffignal. La production de corpus d'occitan médiéval et prémoderne: problèmes et perspectives de travail. In Actes du XINieme\{\} Congrès International de l'Association Internatioale d'Études Occitanes, Albi 2017, 2017. URL https: // halshs . archives-ouvertes . fr/ halshs-02050089/.

Thibault Clérice. pie-extended 0.0.13, 2020. URL https://pypi.org/project/pie-extended/.

Thibault Clérice, Julien Pilla, and Jean-Baptiste-Camps. hipster-philology/pyrrha: 2.0.0, 2019. https:// doi . org/10.5281/zenodo.2541730.

Thibault Clérice, Jean-Baptiste Camps, and Ariane Pinche. Deucalion, modèle ancien francais, 2019. URL http://dx.doi.org/10.5281/zenodo.2539134.

Oksana Dereza. Lemmatisation for under-resourced languages with sequence-to-sequence learning: A case of early irish. In Proceedings of Third Workshop Computational linguistics and language science, volume 4, pages 113-124, 2019.

Sascha Diwersy, Achille Falaise, Marie-Hélène Lay, and Gilles Souvay. Ressources et méthodes pour l'analyse diachronique. Langages, N 206(2):21-44, August 2017. ISSN 0458-726X. URL https://www. cairn. info/revue-langages-2017-2-page-21.htm. 
Frédéric Duval. Les éditions de textes du XVIIe siècle. In David Trotter, editor, Manuel de la philologie de l'édition, pages 369-394. De Gruyter, 2015. ISBN 978-3-11-030260-8. doi: 10. 1515/9783110302608-017. URL https://www. degruyter.com/view/books/9783110302608/ 9783110302608-017/9783110302608-017.xml.

Paul Fièvre. Théâtre classique, 2007. URL http://www .theatre-classique.fr.

Simon Gabay. Pourquoi moderniser l'orthographe? principes d'ecdotique et littérature du XVIIe siècle. Vox Romanica, 73(1):27-42, 2014. ISSN 0042-899X. URL https: / / elibrary.narr.digital/article/ $99.125005 /$ vox201410027.

Simon Gabay and Loïc Barrault. Traduction automatique pour la normalisation du français du XVII e siècle. In TALN 2020, 27ème Conférence sur le Traitement Automatique des Langues Naturelles, Nancy, France, June 2020. ATALA. URL https://hal.archives-ouvertes.fr/hal-02596669.

Simon Gabay, Jean-Baptiste Camps, and Thibault Clérice. Manuel d'annotation linguistique pour le français moderne (xvie -xviiie siècles), 2020a. URL https: / / hal.archives-ouvertes.fr/hal-02571190.

Simon Gabay, Thibault Clérice, Jean-Baptiste Camps, Jean-Baptiste Tanguy, and Matthias Gille-Levenson. Standardizing linguistic data: method and tools for annotating (pre-orthographic) French. In Proceedings of the 2nd International Conference on Digital Tools \& Uses Congress, pages 1-7, $2020 \mathrm{~b}$.

Céline Guillot, Sophie Prévost, and Alexei Lavrentiev. Manuel de référence du jeu Cattex09. École normale supérieure de Lyon, Lyon, 2013a. URL http://bfm.ens-lyon.fr/IMG/pdf/Cattex2009_ manuel_2.0.pdf. Version 2.0-8 avril 2013.

Céline Guillot, Sophie Prévost, and Alexei Lavrentiev. Principes d'annotation cattex09. Technical report, École normale supérieure de Lyon, Lyon, 2013b. version 2.0. http://bfm.ens-lyon. fr/IMG/pdf/ Cattex2009_principes_2.0.pdf.

Céline Guillot-Barbance, Serge Heiden, and Alexei Lavrentiev. Base de français médiéval : une base de référence de sources médiévales ouverte et libre au service de la communauté scientifique. Diachroniques, 7:168-184, 2017. URL https://halshs.archives-ouvertes.fr/halshs-01809581.

Serge Heiden. The TXM platform: Building open-source textual analysis software compatible with the TEI encoding scheme. In 24th Pacific Asia Conference on Language, Information and Computation, pages 389-398. DECODE, Waseda University, 2010.

Georg Heigold, Guenter Neumann, and Josef van Genabith. Neural morphological tagging from characters for morphologically rich languages. arXiv preprint arXiv:1606.06640, 2016.

Nancy Ide and Jean Veronis. Multext: Multilingual text tools and corpora. In COLING 1994 Volume 1: The 15th International Conference on Computational Linguistics, 1994. URL https: / /www acl web.org/ anthology/C94-1097.

Mike Kestemont and Jeroen De Gussem. Integrated Sequence Tagging for Medieval Latin Using Deep Representation Learning. Journal of Data Mining \& Digital Humanities, 2017. URL https : // jdmdh. episciences . org/3835.

Mike Kestemont, Guy de Pauw, Renske van Nie, and Walter Daelemans. Lemmatization for variation-rich languages using deep learning. Digital Scholarship in the Humanities, page fqw034, 2016. ISSN 2055-7671, 2055-768X. doi: 10.1093/llc/fqw034. URL http://dsh.oxfordjournals.org/content/early/2016/08/ 26/lic. fqw034.

Geoffrey Leech and Andrew Wilson. Eagles: Recommendations for the morphosyntactic annotation of corpora. Technical report, Expert Advisory Group on Language Engineering Standards, 1996. URL https :// home . uni-leipzig.de/burr/Verb/htm/LinkedDocuments/annotate.pdf.

Wang Ling, Tiago Luís, Luís Marujo, Ramón Fernandez Astudillo, Silvio Amir, Chris Dyer, Alan W. Black, and Isabel Trancoso. Finding function in form: Compositional character models for open vocabulary word representation. arXiv preprint arXiv:1508.02096, 2015.

Enrique Manjavacas, Ákos Kádár, and Mike Kestemont. Improving Lemmatization of Non-Standard Languages with Joint Learning. arXiv e-prints, art. arXiv:1903.06939, Mar 2019. URL https : / www . aclweb . org/ anthology/N19-1153/.

Enrique Manjavacas, Akos Kádár, and Mike Kestemont. Improving lemmatization of non-standard languages with joint learning. arXiv preprint arXiv:1903.06939, 2019.

Louis Martin, Benjamin Muller, Pedro Javier Ortiz Suárez, Yoann Dupont, Laurent Romary, Éric Villemonte de la Clergerie, Djamé Seddah, and Benoît Sagot. CamemBERT: a Tasty French Language Model. arXiv e-prints, art. arXiv:1911.03894, Nov 2019.

Thomas Müller, Helmut Schmid, and Hinrich Schütze. Efficient higher-order crfs for morphological tagging. In Proceedings of the 2013 Conference on Empirical Methods in Natural Language Processing, pages 322-332, 2013.

Thomas Müller, Ryan Cotterell, Alexander Fraser, and Hinrich Schütze. Joint lemmatization and morphological 
tagging with lemming. In Proceedings of the 2015 Conference on Empirical Methods in Natural Language Processing, pages 2268-2274, Lisbon, Portugal, September 2015. Association for Computational Linguistics. doi: 10.18653/v1/D15-1272. URL https : / / www. aclweb. org/anthology/D15-1272.

Slav Petrov, Dipanjan Das, and Ryan T. McDonald. A universal part-of-speech tagset. CoRR, abs/1104.2086, 2011. URL http: / /arxiv.org/abs/1104.2086.

Prevost Sophie, Stein Achim, SRCMF, 2020. UniversalDependencies/UD_old_french-SRCMF, November 2020. URL https: / / github. com/UniversalDependencies/UD_Old_French-SRCMF. original-date: 2017-05-30T08:20:15Z.

Sophie Prévost and Achim Stein, editors. Syntactic Reference Corpus of Medieval French (SRCMF). ENS de Lyon; Lattice, Paris; ILR University of Stuttgart, Lyon/Stuttgart, v2.6 edition, 2013. URL http: / / srcmf . org.

Sophie Prévost, Céline Guillot, Alexei Lavrentiev, and Serge Heiden. Jeu d'étiquettes morphosyntaxiques CATTEX2009. Technical report, École normale supérieure de Lyon, Lyon, 2013. version 2.0. http: //bfm.ens-1yon.fr/IMG/pdf/Cattex2009_2.0.pdf.

Alain Riffaud. Répertoire du théâtre français imprimé au xviie siècle, 2014. URL https:// repertoiretheatreimprime.yale.edu/.

Laurent Romary, Susanne Salmon-Alt, and Gil Francopoulo. Standards going concrete: from lmf to morphalou. In The 20th International Conference on Computational Linguistics (COLING 2004) - ElectricDict '04 Proceedings of the Workshop on Enhancing and Using Electronic Dictionaries, pages 22-28, 2004. URL https: / / hal . inria.fr/inria-00121489.

Benoît Sagot. External Lexical Information for Multilingual Part-of-Speech Tagging. Research Report RR-8924, Inria Paris, June 2016. URL https: / / hal . inria. fr/hal-01330301.

Benoît Sagot. The lefff, a freely available and large-coverage morphological and syntactic lexicon for french. In Proceedings of the 7th international conference on Language Resources and Evaluation, 2010. URL https://hal.archives-ouvertes.fr/inria-00521242.

Helmut Schmid. Improvements in part-of-speech tagging with an application to german. In Proceedings of the ACL SIGDAT-Workshop, page 47-50, 1995.

Helmut Schmid. Deep learning-based morphological taggers and lemmatizers for annotating historical texts. In Proceedings of the 3rd International Conference on Digital Access to Textual Cultural Heritage, pages 133-137, 2019.

Christof Schöch. Théâtre Classique, paul fièvre (ed.), 2007-2018. RIDE, 8, 2018. URL https : //ride.i-d-e. de/issues/issue-8/theatre-classique.

Gilles Souvay and Jean-Marie Pierrel. Lgerm lemmatisation des mots en moyen français. Traitement Automatique des Langues, 50(2):149-172, 2009. URL https://halshs.archives-ouvertes.fr/ halshs-00396452.

Gongbo Tang, Fabienne Cap, Eva Pettersson, and Joakim Nivre. An Evaluation of Neural Machine Translation Models on Historical Spelling Normalization. arXiv:1806.05210 [cs], 2018. URL http://arxiv.org/ abs/1806.05210.

Isabelle Tellier, Yoann Dupont, and Arnaud Courmet. Un segmenteur-'etiqueteur et un chunker pour le français (a segmenter-pos labeller and a chunker for french)[in french]. In Proceedings of the Joint Conference JEP-TALNRECITAL 2012, volume 5: Software Demonstrations, pages 7-8, 2012.

Assaf Urieli. Robust French syntax analysis: reconciling statistical methods and linguistic knowledge in the Talismane toolkit. PhD thesis, Université Toulouse le Mirail - Toulouse II, 2013. URL https://tel. archives-ouvertes.fr/tel-00979681/.

Denis Vigier and Peter Blumenthal. Presto - l'évolution du système prépositionnel du français, 2013-2017. URL http://presto.ens-lyon.fr.

\section{A PLAYS SAMPLED TO CREATE THE INITIAL TRAINING CORPUS}

The following plays selected from Fièvre [2007] were sampled.

\begin{tabular}{|c|c|c|c|c|c|c|c|c|}
\hline id & auteur & titre & date & genre & inspiration & structure & type & periode \\
\hline CP_DONSANCHE & CORNEILLE, Pierre & $\begin{array}{l}\text { DON } \\
\text { COMÉDIE HÉROIIQUE }\end{array}$ & 1649 & $\begin{array}{l}\text { Comédie } \\
\text { héröque }\end{array}$ & "moeurs espagnoles & 5 act. & 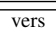 & $1641-1650$ \\
\hline CP_GALERIEDUPALAIS & CORNEILLE, Pierre & $\begin{array}{l}\text { LA GALERIE DU PALAIS ou } \\
\text { L'AMIE RIVALE }\end{array}$ & 1637 & Comédie & moeurs françaises & 5 act. & vers & $1631-1640$ \\
\hline CP_ILLUSIONCOMIQUE & CORNEILLE, Pierre & $\begin{array}{l}\text { L'ILLUSION COMIQUE, } \\
\text { COMÉDIE }\end{array}$ & 1639 & Comédie & moeurs françaises & 5 act. & vers & $1631-1640$ \\
\hline CP_MELITE33 & CORNEILLE, Pierre & $\begin{array}{l}\text { MÉLITE OU LES FAUSSES LET- } \\
\text { TRES, COMÉDIE }\end{array}$ & 1633 & Comédie & moeurs françaises & 5 act. & vers & $1621-1630$ \\
\hline CP_MENTEUR & CORNEILLE, Pierre & LE MENTEUR, COMÉDIE & 1644 & Comédie & moeurs françaises & 5 act. & vers & $1641-1650$ \\
\hline
\end{tabular}




\begin{tabular}{|c|c|c|c|c|c|c|c|c|}
\hline CP_PULCHERIE & CORNEILLE, Pierre & $\begin{array}{l}\text { PULCHÉRIE, } \quad \text { COMÉDIE } \\
\text { HÉROÏQUE }\end{array}$ & 1673 & $\begin{array}{l}\text { Comédie } \\
\text { héroïque }\end{array}$ & histoire chrétienne & 5 act. & vers & $1671-1680$ \\
\hline CP_SUITEMENTEUR & CORNEILLE, Pierre & $\begin{array}{l}\text { LA SUITE DU MENTEUR, } \\
\text { COMÉDIE }\end{array}$ & 1645 & Comédie & moeurs françaises & 5 act. & vers & $1641-1650$ \\
\hline CP_SUIVANTE & CORNEILLE, Pierre & LA SUIVANTE, COMÉDIE & 1637 & Comédie & moeurs françaises & 5 act. & vers & $1631-1640$ \\
\hline CP_TITE & CORNEILLE, Pierre & $\begin{array}{l}\text { TITE ET BÉRÉNICE, COMÉDIE } \\
\text { HEROÏQUE }\end{array}$ & 1671 & $\begin{array}{l}\text { Comédie } \\
\text { héroïque }\end{array}$ & histoire romaine & 5 act. & vers & $1661-1670$ \\
\hline CP_VEUVE34 & CORNEILLE, Pierre & $\begin{array}{l}\text { LA VEUVE OU LE TRAÎTRE } \\
\text { TRAHI, COMÉDIE }\end{array}$ & 1634 & Comédie & moeurs françaises & 5 act. & vers & $1631-1640$ \\
\hline CT_AMOURALAMODE & CORNEILLE, Thomas & $\begin{array}{l}\text { L'AMOUR À LA MODE, } \\
\text { COMÉDIE. }\end{array}$ & 1651 & Comédie & moeurs espagnoles & 5 act. & vers & $1651-1660$ \\
\hline CT_CHARMEDELAVOIX & CORNEILLE, Thomas & $\begin{array}{l}\text { LE CHARME DE LA VOIX, } \\
\text { COMÉDIE }\end{array}$ & 1658 & Comédie & moeurs italiennes & 5 act. & vers & $1651-1660$ \\
\hline CT_COMTESSEORGUEIL & CORNEILLE, Thomas & $\begin{array}{l}\text { LA COMTESSE D'ORGUEIL, } \\
\text { COMÉDIE }\end{array}$ & $1690^{\dagger}$ & Comédie & moeurs françaises & 5 act. & vers & $1651-1660$ \\
\hline CT_DOMBERTRANDECIGARRAL & CORNEILLE, Thomas & $\begin{array}{l}\text { DON BERTRAN DE CIGARRAL, } \\
\text { COMÉDIE }\end{array}$ & $1709^{*}$ & Comédie & moeurs espagnoles & 5 act. & vers & $1651-1660$ \\
\hline CT_DOMCESARDAVALOS & CORNEILLE, Thomas & $\begin{array}{l}\text { DON CÉSAR D'AVALOS, } \\
\text { COMÉDIE. }\end{array}$ & 1661 & Comédie & moeurs espagnoles & 5 act. & vers & $1671-1680$ \\
\hline CT_FEINTASTROLOGUE & CORNEILLE, Thomas & $\begin{array}{l}\text { LE FEINT ASTROLOGUE, } \\
\text { COMÉDIE }\end{array}$ & 1651 & Comédie & moeurs françaises & 5 act. & vers & $1651-1660$ \\
\hline CT_FESTINPIERRE & CORNEILLE, Thomas & $\begin{array}{l}\text { LE FESTIN DE PIERRE, } \\
\text { COMÉDIE }\end{array}$ & 1677 & Comédie & moeurs espagnoles & 5 act. & vers & $1671-1680$ \\
\hline CT_GALANTDOUBLE & CORNEILLE, Thomas & $\begin{array}{l}\text { LE GALANT DOUBLÉ, } \\
\text { COMÉDIE. }\end{array}$ & 1659 & Comédie & moeurs espagnoles & 5 act. & vers & $1651-1660$ \\
\hline CT_GEOLIERDESOISMEME & CORNEILLE, Thomas & $\begin{array}{l}\text { LE GEÔLIER DE SOI-MÊME, } \\
\text { COMÉDIE. }\end{array}$ & 1655 & Comédie & moeurs italiennes & 5 act. & vers & $1651-1660$ \\
\hline CT_ILLUSTRESENNEMIS & CORNEILLE, Thomas & $\begin{array}{l}\text { LES ILLUSTRES ENNEMIS, } \\
\text { COMÉDIE }\end{array}$ & 1657 & Comédie & moeurs espagnoles & 5 act. & vers & $1651-1660$ \\
\hline CT_INCONNU & CORNEILLE, Thomas & L'INCONNU, COMÉDIE. & 1675 & Comédie & moeurs françaises & 5 act. & vers & $1671-1680$ \\
\hline M_AMPHITRYON & MOLIÈRE & AMPHITRYON, COMÉDIE & 1668 & Comédie & mythe grec & $\begin{array}{l}3 \text { act., } \\
\text { prol. }\end{array}$ & vers & $1661-1670$ \\
\hline M_DEPITAMOUREUX & MOLIÈRE & LE DÉPIT AMOUREUX & 1656 & Comédie & moeurs françaises & 5 act. & vers & $1651-1660$ \\
\hline M_DOMGARCIEDENAVARRE & MOLIERE & $\begin{array}{l}\text { DON GARCIE DE NAVARRE, } \\
\text { COMÉDIE }\end{array}$ & $1682 \ddagger$ & Comédie & moeurs espagnoles & 5 act. & vers & $1661-1670$ \\
\hline M_ECOLEDESFEMMES & MOLIÈRE & $\begin{array}{l}\text { L'ÉCOLE DES FEMMES, } \\
\text { COMÉDIE. }\end{array}$ & 1663 & Comédie & moeurs françaises & 5 act. & vers & $1661-1670$ \\
\hline M_ETOURDI & MOLIÈRE & $\begin{array}{l}\text { L'ÉTOURDI ou LES CONTRE- } \\
\text { TEMPS, COMÉDIE }\end{array}$ & 1663 & Comédie & moeurs françaises & 5 act. & vers & $1661-1670$ \\
\hline M_FEMMESSAVANTES & MOLIÈRE & $\begin{array}{l}\text { LES FEMMES SAVANTES, } \\
\text { COMÉDIE }\end{array}$ & 1672 & Comédie & moeurs françaises & 5 act. & vers & $1671-1680$ \\
\hline M_MISANTHROPE & MOLIÈRE & $\begin{array}{l}\text { LE MISANTHROPE ou } \\
\text { L'ATRABILAIRE AMOUREUX, } \\
\text { COMÉDIE }\end{array}$ & 1667 & Comédie & moeurs françaises & 5 act. & vers & $1661-1670$ \\
\hline M_TARTUFFE & MOLIÈRE & $\begin{array}{lc}\text { LE } & \text { TARTUFFE } \\
\text { L'IMPOSTEUR, COMÉDIE } & \text { ou }\end{array}$ & 1669 & Comédie & moeurs françaises & 5 act. & vers & $1661-1670$ \\
\hline O_ABSENTCHEZSOI & $\begin{array}{l}\text { OUVILLE, Antoine le } \\
\text { Métel }\end{array}$ & L'ABSENT CHEZ SOI & 1643 & Comédie & moeurs françaises & 5 act. & vers & $1641-1650$ \\
\hline O_FAUSSESVERITES & $\begin{array}{l}\text { OUVILLE, Antoine le } \\
\text { Métel }\end{array}$ & $\begin{array}{l}\text { LES FAUSSES VÉRITÉS, } \\
\text { COMÉDIE }\end{array}$ & 1643 & Comédie & moeurs françaises & 5 act. & vers & $1641-1650$ \\
\hline O_SOUPCONS & $\begin{array}{l}\text { OUVILLE, Antoine le } \\
\text { Métel }\end{array}$ & $\begin{array}{l}\text { LES SOUPÇONS SUR LES AP- } \\
\text { PARENCES, COMÉDIE }\end{array}$ & 1650 & $\begin{array}{l}\text { héroïco- } \\
\text { comédie }\end{array}$ & moeurs françaises & 5 act. & vers & $1641-1650$ \\
\hline R_BELLEALPHREDE & ROTROU, Jean & $\begin{array}{l}\text { LA BELLE ALPHRÈDE, } \\
\text { COMÉDIE }\end{array}$ & 1639 & Comédie & moeurs arabes & 5 act. & vers & $1631-1640$ \\
\hline R_CAPTIFS & ROTROU, Jean & $\begin{array}{l}\text { LES CAPTIFS OU LES ES- } \\
\text { CLAVES, COMÉDIE }\end{array}$ & 1640 & Comédie & moeurs françaises & 5 act. & vers & $1631-1640$ \\
\hline R_SOSIES & ROTROU, Jean & LES SOSIES, COMÉDIE & 1638 & Comédie & mythe grec & 5 act. & vers & $1631-1640$ \\
\hline S_DOMJAPHETDARMENIE & SCARRON, Paul & $\begin{array}{l}\text { DON JAPHET D'ARMÉNIE, } \\
\text { COMÉDIE. }\end{array}$ & 1653 & Comédie & moeurs françaises & 5 act. & vers & $1651-1660$ \\
\hline S_GARDIENDESOIMEME & SCARRON, Paul & LE GARDIEN DE SOI-MÊME & 1654 & Comédie & moeurs italiennes & 5 act. & vers & $1651-1660$ \\
\hline S_HERITIERRIDICULE & SCARRON, Paul & $\begin{array}{l}\text { L'HÉRITIER RIDICULE OU LA } \\
\text { DAME INTÉRESSÉE.. }\end{array}$ & 1650 & Comédie & moeurs espagnoles & 5 act. & vers & $1641-1650$ \\
\hline S_JODELET & SCARRON, Paul & $\begin{array}{l}\text { LE JODELET OU LE MAÎTRE } \\
\text { VALET, COMÉDIE. }\end{array}$ & 1648 & Comédie & moeurs françaises & 5 act. & vers & $1641-1650$ \\
\hline S_JODELETDUELISTE & SCARRON, Paul & $\begin{array}{l}\text { LE JODELET DUELLISTE, } \\
\text { COMÉDIE. }\end{array}$ & 1646 & Comédie & moeurs françaises & 5 act. & vers & $1641-1650$ \\
\hline S_MARQUISRIDICULE & SCARRON, Paul & $\begin{array}{l}\text { LE MARQUIS RIDICULE, OU } \\
\text { LA COMTESSE faite à la hâte. } \\
\text { COMÉDIE. }\end{array}$ & 1656 & Comédie & moeurs espagnoles & 5 act. & vers & $1651-1660$ \\
\hline
\end{tabular}

$\dagger$ The edition used as base is from 1690, but the play dates back to 1670 .

The edition used as base is from 1709, but the play dates back to 1652 .

$\ddagger$ Created in 1661, but published 1680 . 


\section{B ANNOTATED TEXTS FROM THE FRANTEXT BASE}

The following texts, from ATILF-CNRS and Université de Lorraine [1998-2018], were used as complementary data for lemmatisation training.

\begin{tabular}{|c|c|c|c|c|c|c|}
\hline id & auteur & titre & date & place & publisher & N.tok \\
\hline K639:1890:52916 & LOTI, Pierre & Le Roman d'un enfant & 1891 & Paris & Calmann-Levy & 61,417 \\
\hline K934:1898:35797 & ROSTAND Edmond & Cyrano de Bergerac & 1898 & Paris & Fasquelle & 47,213 \\
\hline K999:1899:45606 & GOURMONT Remy de & Esthétique de la langue française... & 1899 & NA & Soc. Mercure de Fr. & 53,640 \\
\hline L233:1895:13272 & JARRY Alfred & Ubu Roi, Euvres complètes, t. 4. & s.d. & Monte-Carlo & éd. Du Livre & 17,672 \\
\hline L266:1905:59455 & POINCARÉ Henri & La Valeur de la science & 1905 & Paris & Flammarion & 66,125 \\
\hline L433:1882:31745 & BECQUE Henry & Les Corbeaux, Théâtre complet, t. 2 & 1922 & s.p. & Fasquelle & 38.813 \\
\hline L486:1884:68155 & HUYSMANS Joris-Karl & À rebours & 1907 & Paris & Fasquelle & 79,058 \\
\hline L499:1901:63336 & JAURÈS Jean & Études socialistes & 1902 & Paris & Ollendorf & 71,159 \\
\hline L784:1908:100993 & LEROUX Gaston & Le Parfum de la dame en noir & 1908 & Paris & L'Illustration & N.tok \\
\hline L846:1857:68636 & ABOUT Edmond & Le Roi des montagnes & 1857 & s.p. & Hachette & 79,720 \\
\hline L884:1867:20871 & MEILHAC Henri et Ludovic HALÉVY & La Vie parisienne & 1867 & Paris & M. Levy & 27,381 \\
\hline M223:1873:70999 & VERNE Jules & Le Tour du monde en quatre-vingts jours & s.d. & Paris & Hetzel & 84,925 \\
\hline M289:1874:69484 & FROMENTIN Eugène & Un été dans le Sahara & 1877 & Paris & Plon & 80,612 \\
\hline M362:1825:111416 & BRILLAT-SAVARIN Jean-Anthelme & Physiologie du goût... & 1847 & Paris & Charpentier & 127,968 \\
\hline M374:1830:28471 & FOURIER Charles & Le Nouveau monde industriel... & 1830 & Paris & Bossange & 32,566 \\
\hline M425:1794:4621 & CHÉNIER André & L'Invention, CEuvres complètes, t. 2. & 1910 & Paris & Delagrave & 5,473 \\
\hline M433:1807:57291 & STAËL Germaine de & Corinne ou l'Italie : t. 1 & 1807 & s.p. & Peltier & 65,012 \\
\hline M464:1801:72408 & DESTUTT DE TRACY & Élémens d'idéologie, 1 & 1804 & Paris & Courcier & 80,433 \\
\hline M468:1803:62746 & KRÜDENER Barbara Juliane von & Valérie & 1840 & Paris & Charpentier & 73,463 \\
\hline M473:1809:82847 & LAMARCK Jean-Baptiste & Philosophie zoologique : t. 1 & 1809 & s.p. & Dentu & 95,111 \\
\hline M492:1805:123259 & CUVIER Georges & Leçons d'anatomie comparée : t. 1 & 1805 & Paris & Baudouin & 138,674 \\
\hline M528:1798:12861 & GUILBERT DE PIXERÉCOURT & Victor ou l'Enfant de la forêt & 1798 & Paris & Barba & 16,878 \\
\hline M548:1832:199497 & SAY Jean-Baptiste & Traité d'économie politique & 1841 & Paris & Guillaumin & 223,038 \\
\hline M622:1789:24158 & SIEYÈS Emmanuel & Qu'est-ce que le Tiers état? & 1888 & Paris & Soc. Hist. Rév. Fr. & 27,002 \\
\hline M629:1792:31251 & FLORIAN Jean-Pierre & Fables & 1792 & Paris & Didot & 37,172 \\
\hline M893:1869:61374 & GONCOURT Edmond et Jules de & Madame Gervaisais & 1876 & s.p. & Charpentier & 71,174 \\
\hline M939:1852:84555 & COMTE Auguste & Catéchisme positiviste... & 1909 & Paris & Garnier & 95,589 \\
\hline $\mathrm{N} 245: 1838: 32486$ & HUGO Victor & Ruy Blas, Euvres complètes. Théâtre, 3 & 1905 & Paris & Ollendorff & 41,487 \\
\hline N268:1802:63535 & BONALD Louis de & Législation primitive... t. 1 & 1802 & Paris & Le Clère & 72,539 \\
\hline N429:1778:64388 & BUFFON Georges-Louis de & Des époques de la nature, Hist. Natur, t. 5. & 1778 & Paris & Impr. Royale & 70,866 \\
\hline P556:1872:177870 & VIOLLET-LE-DUC Eugène & Entretiens sur l'architecture : t. 2 & 1872 & Paris & A. Morel & 199,695 \\
\hline Q454:1784:53428 & RÉTIF DE LA BRETONNE Nicolas & La Paysanne pervertie...t. 1 & 1784 & s.p. & Vve Duchesne & 64,424 \\
\hline
\end{tabular}

\section{OUT-OF-DOMAIN TEXTS}

Here follows the list of the texts that were sampled for building the out-of-domain test set. Spelling was modernised when necessary.

Theatre texts were sampled from Fièvre [2007], with the exception of:

AUBIGNAC_PUCELLE sample transcribed and modernised from the edition Paris, 1642, available on Gallica.

GRINGORE_SAINT-LOUIS sample transcribed and modernised from the CEuvres complètes, éd. Ch. d'Héricault et A. Montaiglon, Paris, 1858-1877, available on Gallica.

ANOUILH_MEDEE sample transcribed from the Nouvelles pièces noires, Paris, La Table Ronde, 1976.

GIRAUDOUX_ELECTRE sample transcribed from the Théâtre complet, éd. J. Body, Paris, Gallimard, 1982.

CESAIRE_CHRISTOPHE sample transcribed from Poésie, Théâtre, Essais et Discours, éd. Albert James Arnold, Paris, CNRS Editions, 2013.

For the non-dramatic texts, the main sources, as shown in the table, are:

ELEC Éditions en ligne de l'École des chartes, http: / / elec.enc.sorbonne.fr/.

GALL Gallica, Bibliothèque nationale de France, https://gallica.bnf. fr.

WS Wikisource: la bibliothèque libre, https://fr.wikisource.org/.

Other online editions were occasionnaly used:

Correspondance d'Isabelle de Charrière, éd. Suzan van Dijk and Madeleine van Strien-Chardonneau, https : // charriere.huygens.knaw.nl/.

Les Nouvelles Nouvelles (1663) par Jean Donneau de Visé, éd. Claude Bourqui et Christophe Schuwey, http: //www.unifr.ch/nouvellesnouvelles/.

Euvres de Frédéric le Grand - Werke Friedrichs des Großen Digitale Ausgabe der Universitätsbibliothek Trier, dir. Hans-Ulrich Seifert, Trier, http: / / friedrich.uni-trier.de/.

Testaments de Poilus (1914-1918): transcription collaborative, dir. Florence Clavaud, 2018-..., https : / / testaments-de-poilus.huma-num.fr.

The sample from MONTEGUT_ISMENE was transcribed and modernised from the edition Paris, 1768, available on Google Books. 


\subsection{Theatre}

\begin{tabular}{|c|c|c|c|c|c|c|c|c|}
\hline id & author & title & date & genre & inspiration & structure & type & period \\
\hline ANONYME_PARDONNEUR & anonyme & $\begin{array}{l}\text { FARCE } \quad \text { NOUVELLE } \\
\text { BONNE ET } \\
\text { TROIS PERSONNAGES, FARE À } \\
\text { TRONA }\end{array}$ & $1500 \mathrm{c}$. & Farce & Sermon joyeux & 1 act. & vers & $1501-1600$ \\
\hline ANONYME_PONTAUXANES & anonyme & $\begin{array}{l}\text { FARCE NOUVELLE FORT } \\
\text { JOYEUSE DU PONT AUX ÂNES }\end{array}$ & $1500 \mathrm{c}$. & Farce & Sermon joyeux & 1 act. & vers & $1501-1600$ \\
\hline $\begin{array}{l}\text { ANONYME_RESURRECTION- } \\
\text { JENINLANDORE }\end{array}$ & anonyme & $\begin{array}{l}\text { FARCE NOUVELLE TRÈS } \\
\text { BONNE ET FORT JOYEUSE DE } \\
\text { LA RESURRECTION DE JENIN } \\
\text { LANDORE, FARCE }\end{array}$ & $1500 \mathrm{c}$. & Farce & Sermon joyeux & 1 act. & vers & $1501-1600$ \\
\hline ANONYME_SERMONJOYEUX & anonyme & $\begin{array}{l}\text { SERMON JOYEUX DE BIEN } \\
\text { BOIRE, FARCE }\end{array}$ & $1500 \mathrm{c}$. & Farce & Sermon joyeux & 1 act. & vers & $1501-1600$ \\
\hline BEZE_ABRAHAM & BEZE, Théodore & $\begin{array}{l}\text { ABRAHAM } \\
\text { TRAGÉDIE. }\end{array}$ & 1550 & Tragédie & bible & 1 act. & vers & $1541-1550$ \\
\hline GRINGORE_SAINT-LOUIS & GRINGORE, Pierre & Mystère de Saint Louis & 1514 & mystère & histoire médiévale & $\begin{array}{l}8 \\
\text { livres }\end{array}$ & vers & $1511-1520$ \\
\hline JODELLE_CLEOPATRE & JODELLE, Étienne & $\begin{array}{l}\text { CLÉOPÂTRE } \\
\text { TRAGÉDIE. }\end{array}$ & 1574 & Tragédie & histoire romaine & 5 act. & vers & $1571-1580$ \\
\hline JODELLE_DIDON & JODELLE, Étienne & $\begin{array}{l}\text { DIDON SE SACRIFIANT, } \\
\text { TRAGÉDIE. }\end{array}$ & 1574 & Tragédie & mythe grec & 5 act. & vers & $1571-1580$ \\
\hline JODELLE_EUGENE & JODELLE, Étienne & L’EUGÈNE, COMÉDIE. & 1574 & Comédie & moeurs françaises & 5 act. & vers & $1571-1580$ \\
\hline TURNEBE_CONTENTS & TURNÈBE, Odet de & $\begin{array}{llr}\text { LES CONTENTS, } & \text { COMÉDIE } \\
\text { NOUVELLE EN } & \text { PROSE } \\
\text { FRANÇAISE } & & \\
\end{array}$ & 1584 & Comédie & moeurs françaises & 5 act. & prose & $1581-1590$ \\
\hline AUBIGNAC_PUCELLE & $\begin{array}{l}\text { AUBIGNAC, François } \\
\text { Hédelin }\end{array}$ & La Pucelle d’Orléans & 1642 & Tragédie & histoire médiévale & & prose & $1641-1650$ \\
\hline CHAMPREPUS_ULYSSE & $\begin{array}{l}\text { CHAMPREPUS, } \\
\text { Jacques de }\end{array}$ & ULYSSE, TRAGÉDIE. & 1603 & Tragédie & mythe grec & 5 act. & vers & $1601-1610$ \\
\hline CHAPPUZEAU_ARMETZAR & $\begin{array}{l}\text { Samuel Chappuzeau } \\
(1625-1701)\end{array}$ & $\begin{array}{l}\text { ARMETZAR OU LES AMIS EN- } \\
\text { NEMIS, TRAGICOMÉDIE. }\end{array}$ & 1656 & $\begin{array}{l}\text { Tragi- } \\
\text { comédie }\end{array}$ & histoire turque & 5 act. & vers & $1651-1660$ \\
\hline DESHOULIERES_GENSERIC & $\begin{array}{l}\text { DESHOULIÈRES, An- } \\
\text { toinette du Ligier de la } \\
\text { Garde }\end{array}$ & GENSERIC, TRAGÉDIE & 1680 & Tragédie & histoire romaine & 5 act. & vers & $1671-1680$ \\
\hline DESJARDINS_FAVORI & $\begin{array}{l}\text { DESJARDINS, Marie- } \\
\text { Catherine-Hortense } \\
\text { dite de Villedieu }\end{array}$ & LE FAVORI, TRAGICOMÉDIE. & 1665 & $\begin{array}{l}\text { Tragi- } \\
\text { comédie }\end{array}$ & moeurs espagnoles & 5 act. & vers & $1661-1670$ \\
\hline DURANT_OISIVETE & DURANT, Catherine & $\begin{array}{l}\text { OISIVITÉ EST MÈRE DE TOUS } \\
\text { LES VICES, PROVERBE. }\end{array}$ & 1699 & Proverbe & moeurs françaises & 1 act. & prose & $1691-1700$ \\
\hline $\begin{array}{l}\text { MATHIEU_MAGICIENNE- } \\
\text { ETRANGERE }\end{array}$ & MATTHIEU, Pierre & $\begin{array}{l}\text { LA MAGICIENNE ÉTRANGÈRE, } \\
\text { TRAGÉDIE. }\end{array}$ & 1617 & Tragédie & histoire française & 4 act. & vers & $1611-1620$ \\
\hline $\begin{array}{l}\text { SCUDERY_LIGDAMON- } \\
\text { ELIDIAS }\end{array}$ & SCUDERY, Georges de & $\begin{array}{l}\text { LIGDAMON ET LIDIAS, TRAGI- } \\
\text { COMÉDIE }\end{array}$ & 1631 & $\begin{array}{l}\text { Tragi- } \\
\text { comédie }\end{array}$ & histoire médiévale & 5 act. & vers & $1631-1640$ \\
\hline URFE_SYLVANIRE & URFÉ, Honoré d' & $\begin{array}{l}\text { SYLVANIRE ou la MORTE VIVE, } \\
\text { FABLE BOCAGËRE }\end{array}$ & 1627 & $\begin{array}{l}\text { Pastorale } \\
\text { héroïque }\end{array}$ & pastorale & $\begin{array}{l}5 \text { act. } \\
\text { un } \\
\text { pro- } \\
\text { logue }\end{array}$ & vers & $1621-1630$ \\
\hline $\begin{array}{l}\text { VONDREBECK- } \\
\text { ALARD_FORCESDELAMOUR }\end{array}$ & $\begin{array}{l}\text { VONDREBECK, } \\
\text { Maurice et ALARD, } \\
\text { Charles }\end{array}$ & $\begin{array}{l}\text { LES FORCES DE L'AMOUR ET } \\
\text { DE LA MAGIE, DIVERTISSE- } \\
\text { MENT }\end{array}$ & 1678 & Divertissement & moeurs françaises & 3 act. & prose & $1671-1680$ \\
\hline $\begin{array}{l}\text { BERGASSE_JOURNEE- } \\
\text { DESDUPES_1790 }\end{array}$ & $\begin{array}{l}\text { BENSERADE, Isaac } \\
\text { de }\end{array}$ & $\begin{array}{l}\text { LA JOURNÉE DES DUPES, } \\
\text { TRAGI-COMÉDIE }\end{array}$ & 1790 & $\begin{array}{l}\text { Tragi- } \\
\text { comédie }\end{array}$ & histoire française & 4 act. & prose & $1781-1790$ \\
\hline BIEVRE_VERCINGENTORIXE & $\begin{array}{l}\text { BIÈVRE, } \\
\text { Georges } \\
\text { de }\end{array}$ & $\begin{array}{l}\text { VERCINGENTORIXE, } \\
\text { TRAGÉDIE. }\end{array}$ & 1770 & Tragédie & histoire française & 1 act. & vers & $1761-1770$ \\
\hline BOISSY_VIEESTUNSONGE & BOISSY, Louis de & $\begin{array}{l}\text { LA VIE EST UN SONGE, } \\
\text { COMÉDIE-HÉROÏQUE. }\end{array}$ & 1732 & $\begin{array}{l}\text { Comédie } \\
\text { hérö̈que }\end{array}$ & moeurs polonaises & 5 act. & vers & $1731-1740$ \\
\hline DANCOURT_SANCHO & $\begin{array}{l}\text { DANCOURT, Florent } \\
\text { CARTON dit }\end{array}$ & $\begin{array}{l}\text { SANCHO PANÇA, GOU- } \\
\text { VERNEUR, COMÉDIE }\end{array}$ & 1712 & Comédie & moeurs françaises & 5 act. & vers & $1711-1720$ \\
\hline DIDEROT_FILSNATUREL & DIDEROT, Denis & $\begin{array}{l}\text { LE FILS NATUREL ou Les } \\
\text { ÉPREUVES DE LA VERTU. }\end{array}$ & 1757 & $\begin{array}{l}\text { Tragi- } \\
\text { comédie }\end{array}$ & moeurs françaises & 5 act. & prose & $1751-1760$ \\
\hline $\begin{array}{l}\text { DUFRESNY_MARIAGEFAIT- } \\
\text { ETROMPU }\end{array}$ & DUFRESNY, Charles & $\begin{array}{l}\text { LE MARIAGE FAIT ET ROMPU, } \\
\text { COMÉDIE }\end{array}$ & 1721 & Comédie & moeurs françaises & 3 act. & vers & $1721-1730$ \\
\hline GUDIN_LOTHAIRE & $\begin{array}{l}\text { GUDIN de la } \\
\text { BRENELLERIE, } \\
\text { Paul-Philippe }\end{array}$ & $\begin{array}{l}\text { LOTHAIRE, ROI DE LORRAINE, } \\
\text { TRAGÉDIE }\end{array}$ & 1759 & Tragédie & histoire française & 5 act. & vers & $1751-1760$ \\
\hline MARIVAUX_PEREPRUDENT & MARIVAUX, Pierre de & $\begin{array}{l}\text { LE PÈRE PRUDENT } \\
\text { ÉQUITABLE, COMÉDIE }\end{array}$ & 1712 & Comédie & moeurs françaises & 1 act. & vers & $1711-1720$ \\
\hline REGNARD_MENECHMES & $\begin{array}{l}\text { REGNARD, Jean- } \\
\text { François }\end{array}$ & $\begin{array}{l}\text { LES MÉNECHMES, ou LES } \\
\text { JUMEAUX, COMÉDIE }\end{array}$ & 1705 & Comédie & moeurs françaises & 5 act. & vers & $1701-1710$ \\
\hline VOLTAIRE_MORTDECESAR & VOLTAIRE & $\begin{array}{l}\text { LA MORT DE CÉSAR, } \\
\text { TRAGÉDIE EN TROIS ACTES }\end{array}$ & 1736 & Tragédie & histoire romaine & 3 act. & vers & $1731-1740$ \\
\hline ALLAIS_BONBOUGRE & ALLAIS, Alphonse & $\begin{array}{l}\text { LE PAUVRE BOUGRE ET LE } \\
\text { BON GÉNIE, FÉÉRIE EN UN } \\
\text { ACTE. }\end{array}$ & 1889 & Féérie & moeurs françaises & 1 act. & prose & $1881-1890$ \\
\hline AUDE_ECOLETRAGIQUE & AUDE, Joseph & $\begin{array}{l}\text { L'ÉCOLE TRAGIQUE, OU } \\
\text { CADET ROUSSEL MAITRE DE } \\
\text { DÉCLAMATION COMÉDIE }\end{array}$ & 1802 & Comédie & moeurs françaises & 1 act. & mixte & $1801-1810$ \\
\hline BANVILLE_ANCIENPIERROT & $\begin{array}{l}\text { BANVILLE, Théodore } \\
\text { de }\end{array}$ & $\begin{array}{l}\text { ANCIEN PIERROT, MONO- } \\
\text { LOGUE. }\end{array}$ & 1877 & Monologue & moeurs françaises & 1 act. & prose & $1871-1880$ \\
\hline $\begin{array}{l}\text { BONNETAIN_APRESLE- } \\
\text { DIVORCE }\end{array}$ & BONNETAIN, Paul & APRÈS LE DIVORCE, PIÈCE & 1890 & Comédie & moeurs françaises & 1 act. & prose & $1881-1890$ \\
\hline CONSTANT_WALLSTEIN & $\begin{array}{l}\text { CONSTANT, Ben- } \\
\text { jamin }\end{array}$ & WALLSTEIN, TRAGÉDIE & 1809 & Tragédie & histoire allemande & 5 act. & vers & $1801-1810$ \\
\hline DUMAS_DONJUAN & DUMAS, Alexandre & $\begin{array}{l}\text { DON JUAN DE MARANA, MYS- } \\
\text { TĖRE }\end{array}$ & 1836 & Drame & moeurs espagnoles & 5 act. & mixte & $1831-1840$ \\
\hline GENLIS_BELLEETLABETE & 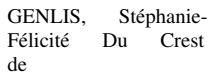 & $\begin{array}{l}\text { LA BELLE ET LA BÊTE, } \\
\text { COMÉDIE }\end{array}$ & 1829 & Comédie & moeurs françaises & 2 act. & prose & $1821-1830$ \\
\hline HUGO_HERNANI & HUGO, Victor & $\begin{array}{l}\text { HERNANI, OU L'HONNEUR } \\
\text { CASTILLAN }\end{array}$ & 1830 & Drame & histoire espagnole & 5 act. & vers & $1821-1830$ \\
\hline JARRY_UBUROI & JARRY, Alfred & UBU ROI, DRAME & 1896 & Drame & Fantaisie historique & 5 act. & mixte & $1881-1890$ \\
\hline SAND_MOLIERE & SAND, George & MOLIÈRE, DRAME. & 1851 & Comédie & histoire littéraire & 2 act. & prose & $1851-1860$ \\
\hline
\end{tabular}




\begin{tabular}{|c|c|c|c|c|c|c|c|c|}
\hline $\begin{array}{l}\text { BERNARDT_PARTIEDE- } \\
\text { BRIDGE }\end{array}$ & BERNARD, Tristan & $\begin{array}{l}\text { LA PARTIE DE BRIDGE, } \\
\text { COMÉDIE }\end{array}$ & 1930 & Comédie & moeurs françaises & 1 act. & prose & 1921-1930 \\
\hline $\begin{array}{l}\text { BERTON_HOMMEQUIA- } \\
\text { TUELAMORT }\end{array}$ & BERTON, René & $\begin{array}{l}\text { L'HOMME QUI A TUÉ LA } \\
\text { MORT, DRAME }\end{array}$ & 1928 & $\begin{array}{l}\text { Pièce } \\
\text { dramatique }\end{array}$ & moeurs françaises & 2 act. & prose & 1921-1930 \\
\hline CESAIRE_CHRISTOPHE & CÉSAIRE, Aimé & La Tragédie du roi Christophe & 1963 & tragédie & histoire haïtienne & 3 act. & prose & $1961-1970$ \\
\hline $\begin{array}{l}\text { COURTELINE_MONSIEUR- } \\
\text { BADIN }\end{array}$ & $\begin{array}{l}\text { COURTELINE, } \\
\text { Georges }\end{array}$ & MONSIEUR BADIN, COMÉDIE. & 1904 & Saynète & moeurs françaises & 1 act. & prose & $1891-1900$ \\
\hline GIRAUDOUX_ELECTRE & GIRAUDOUX, Jean & Électre & 1937 & $\begin{array}{l}\text { tragédie } \\
\text { bourgeoise }\end{array}$ & mythe grec & 2 act. & prose & 1931-1940 \\
\hline HUGUES_CENDRILLON & HUGUES, Clovis & CENDRILLON, COMÉDIE. & 1906 & Comédie & conte de fées & 1 act. & vers & $1901-1910$ \\
\hline HUGUES_TYL & HUGUES, Clovis & TYL L'ESPIEGLE, COMÉDIE. & 1906 & Comédie & moeurs flamande & 1 act. & vers & $1901-1910$ \\
\hline $\begin{array}{l}\text { LESENNE_REVEIL- } \\
\text { CORNEILLE }\end{array}$ & LE SENNE, Camille & $\begin{array}{l}\text { LE RÉVEIL DE CORNEILLE, } \\
\text { POËME DRAMATIQUE. }\end{array}$ & 1916 & $\begin{array}{l}\text { Dialogue } \\
\text { des morts }\end{array}$ & histoire littéraire & 1 act. & vers & 1911-1920 \\
\hline RENARD_MAITRESSE & RENARD, Jules & LA MAÎTRESSE, COMÉDIE. & 1927 & Comédie & moeurs françaises & 2 act. & prose & 1921-1930 \\
\hline
\end{tabular}

\subsection{Varia}

\begin{tabular}{|c|c|c|c|c|c|c|c|}
\hline ID & auteur & titre & genre & forme & date & source & ed. \\
\hline $\begin{array}{l}\text { ANONYME_PAIX- } \\
\text { BERGERAC }\end{array}$ & Chancellerie royale & $\begin{array}{l}\text { Paix de Bergerac. Édit de Poitiers. } \\
\text { Poitiers, septembre } 1577 .\end{array}$ & légal & prose & 1577 & ELEC & $\begin{array}{l}\text { éd. Bernard Barbiche, École na- } \\
\text { tionale des chartes. }\end{array}$ \\
\hline ANONYME_REITRES & anonyme & $\begin{array}{l}\text { Le vray discours sur la route } \\
\text { et admirable desconfiture des } \\
\text { Reistres... }\end{array}$ & discours & prose & 1587 & WS & $\begin{array}{l}\text { éd. Éd. Fournier, Var. hist. et litt., t. } \\
9\end{array}$ \\
\hline ARBEAU_BELLE & Thoinot Arbeau & Belle qui tiens ma vie & chanson & vers & 1588 & WS & manq. \\
\hline $\begin{array}{l}\text { FRANCOISPREMIER- } \\
\text { _CORRESP }\end{array}$ & François Ier & $\begin{array}{l}\text { La correspondance du chancelier } \\
\text { Antoine Du Bourg (1535-1538) }\end{array}$ & correspondance & prose & 1537 & ELEC & éd. Olivier Poncet \\
\hline $\begin{array}{l}\text { LENONCOURT- } \\
\text { MARTIN_HYPNEROTO- } \\
\text { MACHIE }\end{array}$ & $\begin{array}{l}\text { Robert de Lenoncourt, } \\
\text { Jean Martin (trads) }\end{array}$ & $\begin{array}{l}\text { Hypnérotomachie, ou Discours du } \\
\text { songe de Poliphile... }\end{array}$ & discours & prose & 1546 & WS & Jacques Kerver, 1546 \\
\hline LIEBAUT_MISERES & $\begin{array}{l}\text { Liébaut,Nicole Esti- } \\
\text { enne }\end{array}$ & Les Misères de la Femme mariée... & poésie morale & vers & 1587 & WS & $\begin{array}{l}\text { éd. Éd. Fournier, Var. hist. et litt., } \\
3,1855 \text {. }\end{array}$ \\
\hline LOUISELABE_ELEGIE & Louise Labé & Élégie I & poésie lyrique & vers & 1555 & WS & éd. Charles Boy, 1887. \\
\hline $\begin{array}{l}\text { MARGUERITENAVAR- } \\
\text { RE_MIROIR }\end{array}$ & Marguerite de Navarre & Miroir de l'âme pécheresse & miroir & vers & 1529 & WS & éd. Félix Frank, 1873 \\
\hline RABELAIS_PANTAGRUEL & Rabelais & Pantagruel & roman & prose & 1532 & WS & éd. Marty-Laveaux, 1868 \\
\hline RONSARD_SONNETS & Ronsard, Pierre de & $\begin{array}{l}\text { Je plante en ta faveur cet arbre de } \\
\text { Cybèle }\end{array}$ & poésie & vers & 1578 & Ws & éd. Roger Sorg, 1921 \\
\hline ANNEROHAN_PORTRAIT & $\begin{array}{l}\text { Anne de Rohan- } \\
\text { Soubise }\end{array}$ & $\begin{array}{l}\text { Portrait de feue la duchesse de Nev- } \\
\text { ers... }\end{array}$ & poésie & vers & 1629 & GALL & éd. Éd. de Barthélemy, Paris, 1862 \\
\hline ANONYME_AIRABOIRE & anonyme & Air à boire & chanson & vers & $16 \ldots$ & WS & $\begin{array}{l}\text { La Chanson française du XVe au } \\
\text { XXe siècle, éd. Jean Gillequin, } \\
1910 \text {. }\end{array}$ \\
\hline ANONYME_ARREST & anonyme & $\begin{array}{l}\text { Arrest notable donné au profit des } \\
\text { femmes contre l'impuissance des } \\
\text { maris }\end{array}$ & légal & prose & 1626 & WS & $\begin{array}{l}\text { éd. Éd. Fournier, Var. hist. et litt., } \\
6,1856\end{array}$ \\
\hline BOILEAU_SATIRE & Nicolas Boileau & satires (satire I) & satire & vers & 1660 & WS & Paris, 1872 \\
\hline DONNEAU_NOUVELLES & Jean Donneau de Visé & Nouvelles nouvelles & actualité & prose & 1663 & other & éd. Bourqui \& Schuwey \\
\hline $\begin{array}{l}\text { ELISABETHBOHEME- } \\
\text { CORRESPONDANCE }\end{array}$ & Élisabeth de Bohême & $\begin{array}{lll}\text { Correspondance } & \text { avec } & \text { René } \\
\text { Descartes } & & \end{array}$ & correspondance & prose & 1643 & WS & manq. \\
\hline $\begin{array}{l}\text { PERRAULT_PETIT- } \\
\text { CHAPERON }\end{array}$ & Charles Perrault & Le petit Chaperon rouge & conte & prose & 1697 & WS & Paris, 1902 \\
\hline POULLAIN_EGALITE & $\begin{array}{l}\text { François Poullain de La } \\
\text { Barre }\end{array}$ & $\begin{array}{l}\text { De l'Égalité des deux sexes, Dis- } \\
\text { cours phisique et moral }\end{array}$ & discours & prose & 1679 & GALL & Paris, 1679 \\
\hline SCUDERY_ARTAMENE & Madeleine de Scudéry & Artamène ou le Grand Cyrus & roman & prose & 1654 & WS & Auguste Courbé, 1654. \\
\hline VERVILLE_UN-JOUR & Béroalde de Verville & $\begin{array}{l}\text { «Un jour reconnaissant que je suis } \\
\text { incapable» }\end{array}$ & poésie & vers & av. 1626 & WS & manq. \\
\hline ANONYME_DECLARATION & anonyme & $\begin{array}{l}\text { Déclaration des Droits de l'Homme } \\
\text { et du Citoyen de } 1793\end{array}$ & légal & prose & 1793 & WS & manq. \\
\hline CHARRIERE_LETTRE & Isabelle de Charrière & lettre & correspondance & prose & 1755 & other & $\begin{array}{l}\text { éd. S. van Dijk et M. van Strien- } \\
\text { Chardonneau }\end{array}$ \\
\hline CHATELET_DISCOURS & Émilie du Châtelet & Discours sur le bonheur & discours & prose & 1744 & WS & éd. Bourlet de Vauxcelles, 1796 \\
\hline CHENIER_ODE & André Chénier & Ode IX (à Charlotte Corday) & poésie & vers & 1793 & WS & éd. H. de Latouche, 1819 \\
\hline $\begin{array}{l}\text { FREDERICDEUX_DIVINE- } \\
\text { EMILIE }\end{array}$ & Frédéric II de Prusse & À la Divine Émilie & poésie & vers & 1737 & FG & $\begin{array}{l}\text { Euvres de Frédéric le Grand, } \\
\text { Berlin, } 1850\end{array}$ \\
\hline MERICOURT_DISCOURS & $\begin{array}{l}\text { Méricourt, Théroigne } \\
\text { de }\end{array}$ & $\begin{array}{l}\text { Discours devant la Société frater- } \\
\text { nelle des Minimes, } 25 \text { mars } 1792\end{array}$ & discours & prose & 1792 & GALL & Paris, 1792 \\
\hline MONTEGUT_ISMENE & $\begin{array}{l}\text { Jeanne de Montégut- } \\
\text { Ségla }\end{array}$ & Ismene, élégie & poésie & vers & 1739 & other & Paris, 1768 \\
\hline ROUGET_MARSEILLAISE & Rouget de Lisle & La Marseillaise & chanson & vers & 1792 & WS & manq. \\
\hline TENCIN_SIEGE & Madame de Tencin & Le Siège de Calais & roman & prose & 1739 & WS & éd. L.-S. Auger, Paris, 1820. \\
\hline VOLTAIRE_ZADIG & Voltaire & Zadig & nouvelle & prose & 1747 & WS & Paris, 1877. \\
\hline CMH_PV & $\begin{array}{l}\text { Commission des monu- } \\
\text { ments historiques }\end{array}$ & PV 29 février 1884 & administratif & prose & 1884 & ELEC & éd. J.-D. Pariset. \\
\hline DELESCLUZE_LETTRE & Henri Delescluze & $\begin{array}{l}\text { Lettre à Charles Delescluse (Car- } \\
\text { nets de prison) }\end{array}$ & correspondance & prose & 1851 & ELEC & éd. Chr. Nougaret et Fl.Clavaud \\
\hline DEROULEDE_CHANTS & Paul Déroulède & Nouveaux chants du soldat & chanson & vers & 1883 & GALL & Paris, 1883 \\
\hline $\begin{array}{l}\text { DESBORDESVALMORE_IN- } \\
\text { SOMNIE }\end{array}$ & $\begin{array}{l}\text { Marceline Desbordes- } \\
\text { Valmore }\end{array}$ & L'Insomnie & poésie & vers & 1860 & WS & Paris, 1860. \\
\hline HEREDIA_EPEE & Hérédia, José Maria de & L'Épée & poésie & vers & 1893 & WS & Paris, 1893. \\
\hline MERIMEE_ACADEMIE & Prosper Mérimée & $\begin{array}{l}\text { Discours de réception à l'Académie } \\
\text { française }\end{array}$ & discours & prose & 1845 & other & Site de l'Académie française \\
\hline POTTIER_INTERNATIONALE & Eugène Pottier & L'Internationale & chanson & vers & 1871 & WS & Paris, 1908. \\
\hline SAND_MARIANNE & George Sand & Marianne & roman & prose & 1877 & WS & Paris, 1877 \\
\hline SEGUR_BOSSU & Comtesse de Ségur & François le Bossu & roman & prose & 1864 & WS & Paris, 1901 \\
\hline STAEL_ALLEMAGNE & Mme de Staël & De l'Allemagne & essai & prose & 1810 & WS & Paris, 1814 \\
\hline ANONYME_CONSCRITS & anonyme & Les Conscrits insoumis & chanson & vers & 1902 & WS & manq. \\
\hline BLUM_FRONTPOP & Léon Blum & $\begin{array}{l}\text { «Nous sommes un gouvernement } \\
\text { de front populaire» }\end{array}$ & discours & prose & 1936 & GALL & J. O.de la Rép. fr. 7 juin 1936 \\
\hline BRASILLACH_JEANNE & Robert Brasillach & Le Procès de Jeanne d'Arc & étude historique & prose & 1941 & GALL & Paris, 1941 \\
\hline BRIMONT_MIRAGES & Renée de Brimont & Mirages & poésie & vers & 1919 & WS & Paris, 1919 \\
\hline COLETTE_MAISON & Colette & La Maison de Claudine & nouvelle & prose & 1922 & WS & manq. \\
\hline LAHIRE_ROUE & Jean de La Hire & La Roue fulgurante & feuilleton SF & prose & 1908 & GALL & Le Matin, 11 avril 1908 \\
\hline
\end{tabular}




\begin{tabular}{|c|c|c|c|c|c|c|c|}
\hline LASTEYRIE_TESTAMENT & $\begin{array}{l}\text { Gaspard Louis Guy de } \\
\text { Lasteyrie marquis du } \\
\text { Saillant }\end{array}$ & Testament & légal & prose & 1915 & other & Testaments de Poilus \\
\hline LONDRES_BAGNE & Albert Londres & Au bagne & reportage & prose & 1924 & WS & Paris, 1924 \\
\hline NOAILLES_COEUR & Anna de Noailles & Le Coeur innombrable & poésie & vers & 1901 & WS & Paris, 1901 \\
\hline
\end{tabular}

